\title{
Mineralization of biogenic materials in the water masses of the South Atlantic Ocean. II: Stoichiometric ratios and mineralization rates
}

\author{
X.A. Álvarez-Salgado ${ }^{\text {a }}$, M. Álvarez ${ }^{\mathrm{b}, *}$, S. Brea ${ }^{\mathrm{a}}$, L. Mèmery ${ }^{\mathrm{c}}$, M.J. Messias $^{\mathrm{d}}$ \\ a IIM (CSIC), Eduardo Cabello 6, 36208 Vigo, Spain \\ ${ }^{\mathrm{b}}$ IEO, Centro de A Coruña, Apdo. 130, 15080 A Coruña, Spain \\ ' LEMAR, IUEM, Technopole Brest Iroise, 29280 Plouzané, France \\ d UEA, Norwich NR4 7TJ, UK
}

\section{A R T I C L E I N F O}

\section{Article history:}

Received 13 May 2012

Received in revised form 12 November 2013

Accepted 23 December 2013

Available online 13 January 2014

\begin{abstract}
A B S T R A C T
The variability of nitrate $(\mathrm{N})$, phosphate $(\mathrm{P})$, silicate $(\mathrm{Si})$ and Apparent Oxygen Utilization $(\mathrm{AOU})$ due to water mass mixing was objectively separated from the variability due to mineralization of biogenic materials in the western and eastern South Atlantic Ocean on basis of the constrained Optimum MultiParameter (OMP) analysis implemented in the companion manuscript. Using a consensus linear regression model, AOU/N/P/Si mineralization ratios and the corresponding oxygen utilisation rates (OURs) were obtained for the realm of each water mass defined after the OMP analysis. Combining these results with a stoichiometric model, the organic carbon to nitrogen $(\mathrm{C} / \mathrm{N})$ ratios and the biochemical composition (carbohydrates + lipids, proteins and phosphorus compounds) of the mineralized material, were derived. The vertical variability of the $\mathrm{AOU} / \mathrm{N}, \mathrm{AOU} / \mathrm{P}$ and $\mathrm{AOU} / \mathrm{C}$ mineralization ratios pointed to a significant fractionation during the mineralization of sinking organic matter. This fractionation was confirmed by preferential consumption of organic phosphorous compounds and proteins in shallower levels, which produced an increase of the $\mathrm{C} / \mathrm{N}$ ratio of the mineralised materials of $0.5 \pm 0.2 \mathrm{~mol} \mathrm{C} \mathrm{mol} \mathrm{N} \mathrm{N}^{-1}$ every $1000 \mathrm{dbar}$. OURs in the twilight zone decreased quadratically with the $\mathrm{C} / \mathrm{N}$ molar ratio of the mineralised material and exponentially with pressure ( $p$, in $10^{3} \mathrm{dbar}$ ) according to the following regression equation: Ln $($ OUR $)=6.2( \pm 1.2)-2.0( \pm 0.7) * \operatorname{Ln}(\mathrm{C} / \mathrm{N})-0.6( \pm 0.2) * p\left(r^{2}=0.87, p<0.006, n=8\right)$. This variability in the rates and stoichiometric ratios of the biogenic material mineralization compromises our capacity to predict the ocean biogeochemistry response to global change, including the $\mathrm{CO}_{2}$ uptake and storage and the corresponding feedback mechanisms.
\end{abstract}

(c) 2014 Elsevier Ltd. All rights reserved.

\section{Introduction}

This is the second part of a study conducted with the general aim of determining the quality of the mineralized biogenic materials, the corresponding mineralization rates, and the close relationship between quality and lability in the different water masses that circulate and mix in the South Atlantic. The data used here are the same as those in Álvarez et al. (this issue), who assessed the outputs and uncertainties of a constrained Optimum MultiParameter (OMP) analysis to solve the mixing of water masses in the South Atlantic Ocean.

Once the optimum Source Water Type (SWT) fractions have been calculated by Álvarez et al. (this issue), the effect of mixing and mineralization of biogenic materials on the distributions of nitrate $(N)$, phosphate (P), silicate (Si), Apparent Oxygen Utilization (AOU) and Oxygen Utilization Rate (OUR) can be objectively separated. In this

\footnotetext{
* Corresponding author. Tel.: +34 981218171.

E-mail address: marta.alvarez@co.ieo.es (M. Álvarez).
}

manuscript, we will consider: (i) the relative contribution of mixing and mineralization to the distributions of nitrate, phosphate, silicate and apparent oxygen utilisation; (ii) the $\mathrm{AOU} / \mathrm{N} / \mathrm{P} / \mathrm{Si}$ mineralization ratios using a consensus linear regression model; (iii) the biochemical composition and fractionation of the mineralized materials during the mineralization process; and (iv) the mineralization rates (sensu OUR) and their relationship with the biochemical composition of the biogenic materials within the realm of each water mass. These four objectives are issues discussed nowadays within the community of marine biogeochemists interested on the role of the meso- and bathypelagic World Ocean as a $\mathrm{CO}_{2}$ storage and any feedbacks between climate change and the global carbon cycle. The relative importance of preformed nutrients in the formation areas of the water masses that mix in any ocean basin compared with the intensity (rate) and extension (time) of the mineralization processes that occur during that mixing define the nutrient ratios of the oceans (Weber and Deutsch, 2010). Different mineralization rates for $\mathrm{C}-, \mathrm{N}$ - and $\mathrm{P}$-rich biogenic molecules would lead to a 
fractionation during the mineralization process (Shaffer et al., 1999; Brea et al., 2004), since P is mineralized faster than $\mathrm{N}$ and the latter faster than C (Tegelaar et al., 1989; Middelburg et al., 1993; Hopkinson et al., 2002; Boyd and Trull, 2007; Lonborg et al., 2009). This fractionation should be observed between different water masses as a function of their respective depth range and within the same water masses throughout its route from the formation area. Mineralization of $\mathrm{P}$ - and $\mathrm{N}$-rich compounds in the shallower water masses and closer to the formation areas would have clear implications for the preservation of C-rich compounds in certain areas and depths of the World Ocean, which undoubtedly would affect its potential to sequester $\mathrm{CO}_{2}$ (Omta et al., 2006; Schneider et al., 2004; Kwon et al., 2009).

\section{Methods}

\subsection{Objective separation of SWT mixing from biogenic organic matter} mineralization

Once the SWT proportions have been obtained by means of the OMP analysis presented in Álvarez et al. (this issue), the following equation can be written for any non-conservative (NC) variable:

$X \cdot A=\mathrm{NC}$

where $X$ is the $(n \times 13)$ matrix of SWT proportions, NC is the $(n \times 1)$ matrix of the measured non-conservative variable and $A$ is the corresponding matrix $(13 \times 1)$ of SWT type nitrate, phosphate, silicate or apparent oxygen utilisation, $n$ being the number of samples. Matrices $X$ and NC are known and matrix $A$ is our unknown. This system of linear equations can be solved as follows:

$A=\left(X^{T} \cdot X\right)^{-1} \cdot X^{T} \cdot \mathrm{NC}$

where $X^{T}(13 \times n)$ is the transpose of $X$. We used a Non-Negative Least Squares (NNLS) method in which all the elements in $A$ are forced to be $\geqslant 0$. The resulting SWT type values for any non-conservative variable are the concentrations that produce the best estimate (in a leastsquares sense) of the measured concentrations when the SWT proportions (matrix $X$ ) are multiplied by the corresponding SWT type values (matrix $A$ ) i.e., the product $X$. $A$ would yield the potential distribution of tracers if they were conservative. SWT concentrations should not be confused with preformed concentrations. The preformed values are the expected concentrations at the time of SWT formation; waters formed by convection and subduction (e.g., mode waters) have an AOU not significantly different from zero (Broecker and Peng, 1982; Chester, 2000; Tomczak, 1999) and very low nutrient levels while this is not the case for those formed by subsurface mixing as the CDW (Tomczak, 1999). Therefore, SWT type values retain the variability due to: (i) preformed conditions and (ii) the mineralization of biogenic materials from the formation area of each SWT to the study area (Pérez et al., 1993; Castro et al., 1998).

Consequently, the values of NC recalculated from the product of matrices $X$ and $A$ differ from the actual values of the matrix NC in such a way that whereas $X \cdot A$ would retain the variability of NC due to SWT mixing and large-scale mineralization from the formation to the study area, the residuals, $\triangle \mathrm{NC}(=\mathrm{NC}-X \cdot A)$, would retain the variability associated with mineralization processes in the study area. In our case, the study area is the whole South Atlantic Ocean. Therefore, $\triangle \mathrm{NC}$ would reflect differences in the mineralization patterns between and within WOCE lines A14 and A17.

Table 1 shows the source water type values for AOU, N, P and Si. Note that the $\mathrm{Si}$ type values practically coincided with those in $\mathrm{Ta}-$ ble 2 in Álvarez et al. (this issue) because $\mathrm{Si}$ is considered non-conservative only in Central Waters, those above the permanent thermocline. Central Waters are the recently formed mode waters, and therefore Salinity Maximum Water $\left(\mathrm{SMW}_{27}\right)$, Subtropical
Table 1

Source water type values for the non-conservative parameters nitrate $(\mathrm{N})$, phosphate $(\mathrm{P})$, silicate (Si) and Apparent Oxygen Utilisation (AOU) in the SWT realms depicted in Fig. 1. Units in $\mu \mathrm{mol} \mathrm{kg}^{-1}$. SMW ${ }_{27}$, Salinity Maximum Water; STMW ${ }_{18}$, Subtropical Mode Water; $\mathrm{EQ}_{13}$, Equatorial Central Water of $13{ }^{\circ} \mathrm{C}$; SACW- $\mathrm{E}_{18}$, warm subequatorial South Atlantic Central Water; SACW-E ${ }_{12}$, cold subequatorial South Atlantic Central Water; SACW-T $\mathrm{T}_{18}$, warm subtropical South Atlantic Central Water; SACW-T ${ }_{12}$, cold subtropical South Atlantic Central Water; AAIW ${ }_{5}$, Subantarctic Mode Water; AAIW Antarctic Intermediate Water; $\mathrm{CDW}_{1,6}$, Circumpolar Deep Water; NADW 4 , upper + middle North Atlantic Deep Water; $\mathrm{NADW}_{2}$, lower North Atlantic Deep Water; WSDW W. $_{-3}$, Weddell Sea Deep Water. The subscript in the acronyms stands for the SWT potential temperature.

\begin{tabular}{lrlrr}
\hline & \multicolumn{1}{c}{$\mathrm{N}$} & \multicolumn{1}{l}{$\mathrm{P}$} & \multicolumn{1}{c}{$\mathrm{SOU}$} \\
\hline Central Waters & & & & \\
SMW $_{27}$ & $0.6 \pm 0.6$ & $0.15 \pm 0.04$ & $0 \pm 6$ & $1.1 \pm 0.2$ \\
STMW $_{18}$ & $1.0 \pm 0.5$ & $0.15 \pm 0.03$ & $7 \pm 5$ & $1.3 \pm 0.2$ \\
EQ $_{13}$ & $17.8 \pm 0.2$ & $1.19 \pm 0.01$ & $109 \pm 2$ & $5.2 \pm 0.1$ \\
SACW-E $_{18}$ & $8.8 \pm 0.4$ & $0.68 \pm 0.03$ & $54 \pm 4$ & $3.2 \pm 0.1$ \\
SACW-E $_{12}$ & $30.5 \pm 0.3$ & $1.93 \pm 0.02$ & $218 \pm 2$ & $10.1 \pm 0.1$ \\
SACW-T $_{18}$ & $0.0 \pm 0.3$ & $0.18 \pm 0.02$ & $9 \pm 3$ & $1.5 \pm 0.1$ \\
SACW-T $_{12}$ & $11.8 \pm 0.2$ & $0.85 \pm 0.01$ & $46 \pm 2$ & $3.6 \pm 0.1$ \\
Intermediate $_{\text {waters }}$ & $32.6 \pm 0.2$ & $2.27 \pm 0.02$ & $131 \pm 2$ & $6.9 \pm 0.1$ \\
AAIW & & & $57 \pm 2$ & $16.3 \pm 0.1$ \\
AAIW $_{3}$ & $31.0 \pm 0.2$ & $2.08 \pm 0.01$ & & \\
Deep $_{\text {waters }}$ & & & & \\
CDW $_{1.6}$ & $38.9 \pm 0.2$ & $2.69 \pm 0.01$ & $203 \pm 2$ & $110.7 \pm 0.1$ \\
NADW $_{4.6}$ & $21.8 \pm 0.1$ & $1.43 \pm 0.01$ & $88 \pm 1$ & $7.1 \pm 0.04$ \\
NADW $_{2}$ & $17.6 \pm 0.1$ & $1.17 \pm 0.01$ & $49 \pm 1$ & $29.0 \pm 0.03$ \\
Bottom $_{\text {waters }}$ & & & & \\
WSDW $_{-0.3}$ & $34.1 \pm 0.1$ & $2.33 \pm 0.01$ & $129 \pm 1$ & $135.0 \pm 0.04$ \\
\hline
\end{tabular}

Table 2

Source water archetypal values for latitude, longitude, pressure and volume along each section.

\begin{tabular}{|c|c|c|c|c|}
\hline & Lat $\left({ }^{\circ} \mathrm{N}\right)$ & Lon $\left({ }^{\circ} \mathrm{E}\right)$ & Pres (dbar) & Vol. (\%) \\
\hline \multicolumn{5}{|l|}{ A14 } \\
\hline$S A C W-E_{18}$ & -1.50 & 7.53 & 116 & 2.1 \\
\hline SACW-E 12 & -4.73 & 7.95 & 327 & 6.0 \\
\hline $\mathrm{SACW}-\mathrm{T}_{18}$ & -28.81 & 9.00 & 187 & 2.1 \\
\hline SACW-T 12 & -30.40 & 9.00 & 379 & 7.4 \\
\hline AAIW & -25.85 & 8.75 & 863 & 17.0 \\
\hline UCDW & -24.49 & 8.72 & 1354 & 9.3 \\
\hline $\mathrm{NADW}_{4.6}$ & -11.86 & 8.23 & 1909 & 14.4 \\
\hline $\mathrm{NADW}_{2}$ & -17.16 & 8.44 & 3128 & 30.2 \\
\hline LCDW & -22.89 & 8.64 & 3343 & 10.7 \\
\hline WSDW $_{-0.3}$ & -33.43 & 8.60 & 3937 & 0.8 \\
\hline \multicolumn{5}{|l|}{$A 17$} \\
\hline $\mathrm{SMW}_{27}$ & -17.23 & -32.64 & 119 & 0.8 \\
\hline STMW $_{18}$ & -23.98 & -38.60 & 166 & 1.6 \\
\hline $\mathrm{EQ}_{13}$ & -22.96 & -35.44 & 159 & 2.1 \\
\hline SACW-T 18 & -14.18 & -37.72 & 379 & 8.7 \\
\hline AAIW & -25.90 & -41.61 & 816 & 13.6 \\
\hline UCDW & -24.94 & -41.41 & 1424 & 7.5 \\
\hline $\mathrm{NADW}_{4.6}$ & -9.62 & -36.45 & 1870 & 17.2 \\
\hline $\mathrm{NADW}_{2}$ & -11.33 & -36.66 & 3230 & 28.4 \\
\hline LCDW & -27.90 & -41.79 & 3575 & 6.4 \\
\hline WSDW $_{-0.3}$ & -28.08 & -41.18 & 4645 & 13.8 \\
\hline
\end{tabular}

Mode Water $\left(\mathrm{STMW}_{18}\right)$ and warm South Atlantic Central Water (SACW-T ${ }_{18}$ ) presented AOU type values close to saturation and low nutrient type concentrations. On the contrary, Equatorial South Atlantic Central Water and the densest cold South Atlantic Central Water (SACW-T $\mathrm{T}_{12}$ ) were characterised by high AOU and nutrient type values, indicating a more intense organic matter mineralization from the formation to the study area. Within the intermediate, deep and bottom waters, the highest AOU type value corresponded to Circumpolar Deep Water $\left(\mathrm{CDW}_{1.6}\right)$ formed by subsurface mixing of mineralized deep waters within the Circumpolar Current (see Álvarez et al., this issue). 
Table 3

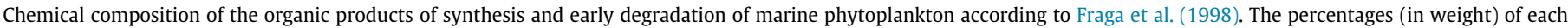
group correspond to the average composition of marine phytoplankton.

\begin{tabular}{|c|c|c|c|}
\hline & Chemical formula & Formula weight $(\mathrm{g} / \mathrm{mol})$ & Contribution (in weight) (\%) \\
\hline Proteins $^{\mathrm{a}}$ & $\mathrm{C}_{147} \mathrm{H}_{228} \mathrm{O}_{46} \mathrm{~N}_{40} \mathrm{~S}$ & 1431.6 & 48 \\
\hline Carbohydrates & $\mathrm{C}_{6} \mathrm{H}_{10} \mathrm{O}_{5}$ & 3325.3 & 23 \\
\hline Lipids $^{\mathrm{b}}$ & $\mathrm{C}_{53} \mathrm{H}_{89} \mathrm{O}_{6}$ & 822.3 & 18 \\
\hline Phosphorus compounds ${ }^{c}$ & $\mathrm{C}_{45} \mathrm{H}_{76} \mathrm{O}_{31} \mathrm{~N}_{12} \mathrm{P}_{5}$ & 456.4 & 12 \\
\hline Average composition & $\mathrm{C}_{106} \mathrm{H}_{171} \mathrm{O}_{41} \mathrm{~N}_{16} \mathrm{P}$ & 2372.8 & 100 \\
\hline
\end{tabular}

a Chlorophylls are included in proportion $4 \%$ in weight.

b Phospholipids are excluded.

c All inorganic and organic phosphorus compounds are included.

\subsection{Archetypal SWT values}

For any variable, an archetypal value $\left(\mathrm{A}_{\mathrm{T}}\right)$ for the realm of each SWT can be calculated as follows:

$A_{T i}=\frac{\sum_{j} x_{i j} \cdot \operatorname{Var}_{i}}{\sum_{j} x_{i j}}$

where $x_{i j}$ is the proportion of SWT $i$ on sample $j$ and $V a r_{i}$ is the value of any variable in sample $i$. Therefore, archetypal values are a sort of weighted mean value of any SWT property along each section. This methodology was also applied by Álvarez-Salgado et al. (2013) and Guerrero-Feijóo et al. (2014) to study the variability of dissolved organic carbon in the northern and southern Atlantic Ocean, respectively. Table 2 summarises the archetypal location, pressure and volume of each SWT in the western (A17) and eastern (A14) South Atlantic Ocean. Archetypal longitude, latitude and pressure are relevant to compare the route of each SWT from the water mass formation to the study area. The archetypal volume would express the fraction (in percentage) of the study WOCE line occupied by each water mass, calculated as $100 \times \sum_{j} x_{i j} / n$, where $n$ stands for the total number of samples analyzed by the OMP mixing model, 4469 for the A17 line and 2742 for the A14.

\subsection{Stoichiometric model}

Once the AOU, $N$ and $P$ residuals ( $\triangle A O U, \Delta N$ and $\Delta P$ ) have been obtained (see Section 2.1), the biochemical composition of the mineralised material can be estimated from the biochemical formulas of the products of early degradation of marine phytoplankton. Assuming that changes in the chemical composition of marine phytoplankton are due to variations in the proportions of carbohydrates, lipids, proteins and phosphorus compounds rather than variations in the molecular formula of each group (Álvarez-Salgado et al., 2006), it is possible to estimate their proportions as stated by Fraga et al. (1998). The average elemental composition of proteins (Prt), carbohydrates (Cbh), lipids (Lip) and phosphorus compounds (Pho) are shown in Table 3. From these chemical formulas, the contribution of the different biomolecules to the mineralized phytogenic organic matter can be calculated from $\triangle \mathrm{AOU}, \Delta \mathrm{N}$ and $\Delta \mathrm{P}$ with the following sets of equations:

$$
\begin{aligned}
& \mathrm{C}_{147} \mathrm{H}_{228} \mathrm{O}_{46} \mathrm{~N}_{40} \mathrm{~S}+232.5 \mathrm{O}_{2}+189 \mathrm{OH}^{-} \\
& \rightarrow 147 \mathrm{HCO}_{3}^{-}+40 \mathrm{NO}_{3}^{-}+\mathrm{SO}_{4}^{2-}+135 \mathrm{H}_{2} \mathrm{O} \\
& \mathrm{C}_{6} \mathrm{H}_{10} \mathrm{O}_{5}+6 \mathrm{O}_{2}+6 \mathrm{OH}^{-} \rightarrow 6 \mathrm{HCO}_{3}^{-}+5 \mathrm{H}_{2} \mathrm{O} \\
& \mathrm{C}_{53} \mathrm{H}_{89} \mathrm{O}_{6}+72.25 \mathrm{O}_{2}+53 \mathrm{OH}^{-} \rightarrow 53 \mathrm{HCO}_{3}^{-}+44.5 \mathrm{H}_{2} \mathrm{O} \\
& \mathrm{C}_{45} \mathrm{H}_{76} \mathrm{O}_{31} \mathrm{~N}_{12} \mathrm{P}_{5}+70.75 \mathrm{O}_{2}+67 \mathrm{OH}^{-} \\
& \rightarrow 45 \mathrm{HCO}_{3}^{-}+12 \mathrm{NO}_{3}^{-}+5 \mathrm{HPO}_{4}^{2-}+46.5 \mathrm{H}_{2} \mathrm{O}
\end{aligned}
$$

And the corresponding linear system of mass balance equations is:

$\Delta \mathrm{AOU}=232.5 \times \operatorname{Prt}+6 \times \mathrm{Cbh}+72.25 \times \mathrm{Lip}+70.75 \times$ Pho

$\Delta \mathrm{N}=40 \times \operatorname{Prt}+12 \times$ Pho

$\Delta \mathrm{P}=5 \times \mathrm{Pho}$

This is a system of 3 equations with 4 unknowns (Cbh, Lip, Prt and Pho) has not a unique solution. Whereas the amounts of Prt and Pho are determined by Eqs. (9) and (10), the amounts of Cbh and Lip are undetermined. Although the $\mathrm{Cbh} / \mathrm{Lip}$ ratio in fresh marine phytoplankton is around 0.45 (Fraga et al., 1998), following Álvarez-Salgado et al. (2006), we calculated the range of possible biochemical compositions compatible with a net mineralization of at least $5 \%$ of $\mathrm{Cbh}(\mathrm{Cbh} / \mathrm{Lip}$ ratio of 0.05$)$ on one extreme and at least $5 \%$ of Lip (Cbh/Lip ratio of 19 ) on the other extreme.

The $\Delta \mathrm{AOU} / \Delta \mathrm{P}$ and $\Delta \mathrm{N} / \Delta \mathrm{P}$ as well as any other nutrient ratio within the realm of any SWT will be obtained from the slope of the linear regression between $\Delta \mathrm{AOU}$ and $\Delta \mathrm{P}$ or $\Delta \mathrm{N}$ and $\Delta \mathrm{P}$, respectively.

\subsection{CFC apparent ages}

As described in the corresponding cruise reports (Groupe CITHER-2, 1996; Groupe CITHER-3, 1998), CFC-11 concentrations in seawater were measured using a shipboard electron capture gas chromatography (EC-GC) technique similar to that described by Bullister and Weiss (1988). The overall accuracy for dissolved CFC-11 measurements was estimated to be $2 \%$ or $0.02 \mathrm{pmol} \mathrm{kg}^{-1}$, whichever is greater. CFC-11 concentrations were converted to partial pressures using the solubility function by Warner and Weiss (1985).

The CFC-11 apparent age $(\tau)$ of any water sample was calculated following Doney and Bullister (1992) assuming 100\% initial saturation. Reconstructed CFC-11 annual mean dry air mole fractions in the Southern Hemisphere were taken after Walker et al. (2000). Apparent ages were calculated for the Central Water and Antarctic Intermediate Water (AAIW) realms defined after the OMP results in Álvarez et al. (this issue). In these realms, we restricted our analysis to CFC-11 concentrations $>0.016 \mathrm{pmol} \mathrm{kg}-1$ and apparent ages lower than 35 years. Two main sources of error apart for the analytical uncertainty make apparent ages differ from true ages: the degree of CFC-11 saturation at the time of water mass formation and the dispersion and mixing of the water parcel (e.g., Doney and Bullister, 1997; Sonnerup, 2001; Mecking et al., 2004). Based on extensive CFC observations at the sea surface, a $100 \%$ saturation can be safely assumed for central and intermediate waters but not for deep and bottom waters where under-saturation can reach 60\% (Wallace and Lazier, 1988; Wallace et al., 1994). Mixing effects on apparent ages were assumed to be minimal because we centred our study in waters formed between 
1960 and 1995, when the atmospheric CFC-11 increase was practically linear (Sonnerup, 2001; Thiele and Sarmiento, 1990) and because we followed the core of each water mass, where the water mass proportions derived from the OMP analysis were $>50 \%$ (for more details, see Álvarez et al., this issue).

\subsection{OURs}

Oxygen Utilization Rates (OURs) can be estimated from the slope of the relation between AOU and apparent CFC-11 ages $(\tau)$ within the Central and AAIW realms, i.e. within the twilight zone (Buesseler and Boyd, 2009), of each WOCE section. Three sets of AOU and $\tau$ values can be used: (i) directly measured AOU and $\tau$ (OUR $\left.R_{D}\right)$; (ii) OMP type values of AOU and $\tau\left(\mathrm{OUR}_{\mathrm{T}}\right)$; and (iii) OMP residual values of $\mathrm{AOU}$ and $\tau\left(\mathrm{OUR}_{\Delta}\right)$. As described in Álvarez et al. (this issue), OMP type values account for the water mass mixing and large-scale mineralisation processes affecting non-conservative variables (from the water mass formation to the study area) while local mineralization processes or non-linear mixing effects are retained in the OMP residuals.

\subsection{Water mass realms}

The aims detailed in the introduction about oxygen and inorganic nutrients variability (Section 3), mineralization ratios (Section 4), fractionation of organic matter mineralization (Sections 5 and 6), and OURs (Sections 7 and 8) will be attained studying the realm of each water mass in the South Atlantic Ocean (SAO). For the purposes of this work, the realm of a water mass along the two WOCE lines will comprise all samples with more than $50 \%$ contribution of the corresponding individual or combined
SWT (Fig. 1). Note that in Fig. 1, AAIW corresponds to the sum of types AAIW 5 and $\mathrm{AAIW}_{3}$. In line A17, SWM 27 occupies less than $1 \%$ of the volume (Table 1 ) and it was not considered in this study. Along line A14, Weddell Sea Deep Water $\left(W_{S D W}-0.3\right)$ represents less than $1 \%$ of the total A14 volume (Section 2.2) (Table 1) as the maximum percentage contribution along the line is less than $45 \%$ to the south of $35^{\circ} \mathrm{S}$ (Fig. $5 \mathrm{~b}$ in Álvarez et al., this issue); it will be neither considered. The OMP separated Upper and Lower CDW (Figs. 5 and 6 in Álvarez et al., this issue) although using only one SWT, CDW ${ }_{1.6}$. Samples with more than $50 \% \mathrm{CDW}_{1.6}$ and less than 2500 dbar (A17 line) and 2250 dbar (A14 line) were considered as Upper CDW (UCDW). Accordingly, samples with more than $50 \% \mathrm{CDW}_{1.6}$ and deeper than those pressure levels were considered as Lower CDW (LCDW).

\subsection{Consensus linear regression model}

Linear regression is the most recurrently used statistical tool in oceanography and marine ecology to: (i) quantify the level of dependence between two variables; (ii) analyse the functional relationship between them; or (iii) predict the dependent $\left(Y^{\mathrm{var}}\right)$ from the independent ( $X^{\mathrm{var}}$ ) variable (Sokal and Rolhf, 1995). Cases (ii and iii) are sensitive to the least square model used to fit the empirical data: ordinary (model I), orthogonal or geometric mean (model II). The convenience of using regression models I or II has been a question of long-lasting debate among marine ecologists (e.g. Ricker, 1973; Laws and Archie, 1981; Fuller, 1987; Prairie et al., 1995; Laws, 2003; Calbet and Prairie, 2003; McArdle, 2003). However, this dispute has not impinged on marine biogeochemists, particularly on those interested in the assessment of mineralization ratios of biogenic structures in the oceans from
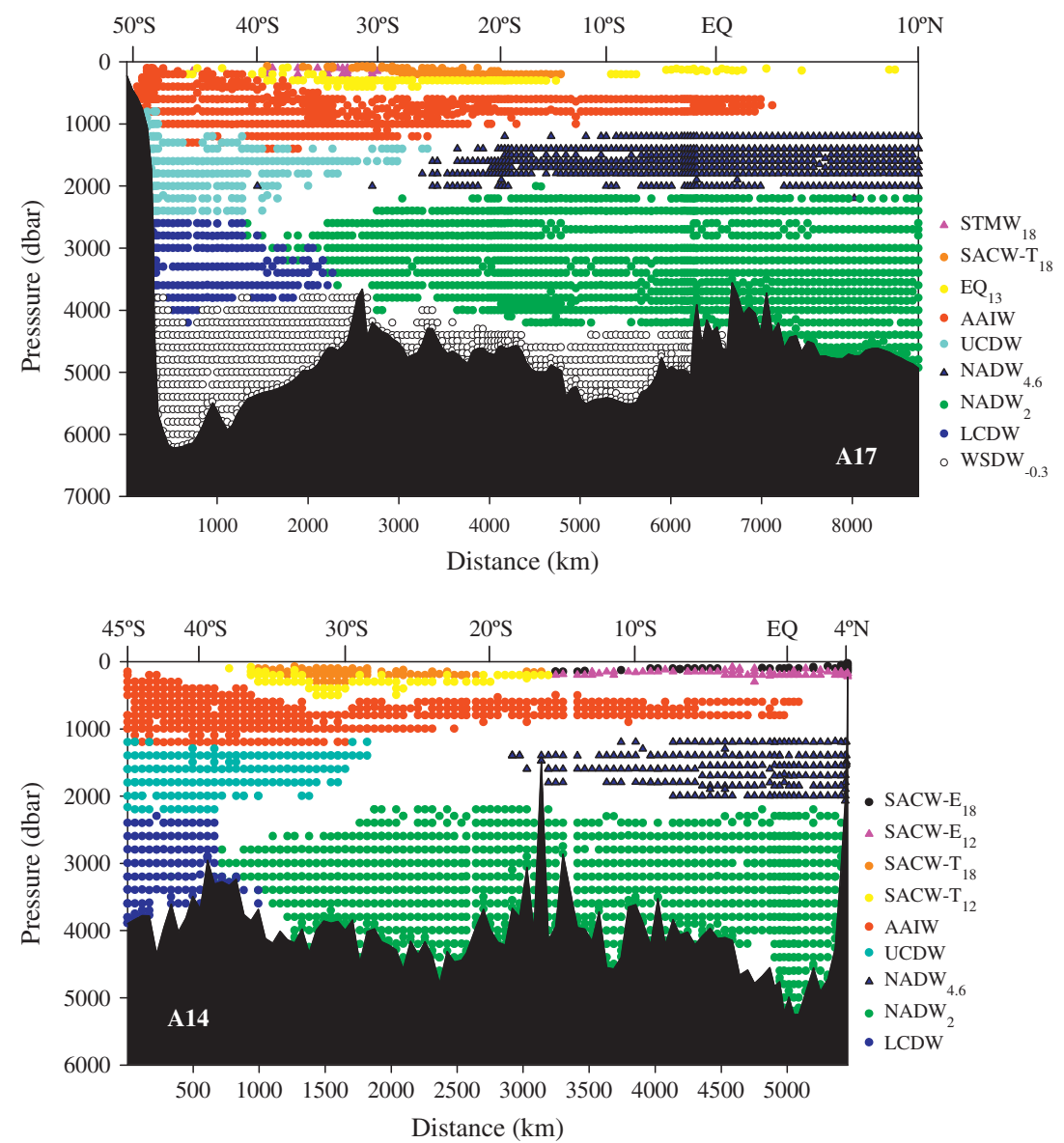

Fig. 1. Water mass realms within (upper panel) WOCE line A17 and (lower panel) WOCE line A14. 
measured dissolved oxygen, inorganic carbon and nutrient data. Since ordinary least squares (OLS) regression is the default option in statistical packages, regression model I of $Y^{\mathrm{var}}$ on $X^{\mathrm{var}}$ has been traditionally used in most studies.

Following Sokal and Rohlf (1995), regression model I should be used when the independent (explanatory) variable $X^{\mathrm{var}}$ does not vary at random but is under the control of the investigator and regression model II when the independent variable is also measured with error. Strictly considering this recommendation, the default regression model should be model II for most environmental field studies. However, Sokal and Rolf (1995) are implicitly assuming that: (i) in the absence of a measurement error the data fall exactly on a straight line, something that is true only when the two variables are related by a physical law (Prairie et al., 1995; Carrol and Ruppert, 1996; McArdle, 2003; Warton et al., 2006); and (ii) the measurement error variances of $X^{\mathrm{var}}$ and $Y^{\mathrm{var}}$ are not significantly different.

In the particular case of the computation of ocean mineralization rates and ratios, it is clear that the dispersion of the field data around a straight line is not exclusively due to analytical error of the determination of the measured variables or to the representativeness of the collected samples along an isopycnal surface, i.e. the sampling error. Other factors such as the heterogeneity of the composition of the mineralised biogenic materials within that isopycnal surface should also be considered. Therefore (i) dissolved oxygen, nutrient salts or water mass age are not determined with the same "measurement error", i.e. sampling + analytical error; and (ii) the relation between these variables do not fall exactly on a straight line but there is an "equation error" too (Fuller, 1987). On this basis, McArdle (2003) introduced the term "asymmetric relationship" when there is no equation error added to the independent variable and "symmetric relationship" when there is no clear dependent and independent variable because both contribute to the equation error. Alternatively, Warton et al. (2006) stated that regression model I should be used to predict $Y^{\mathrm{var}}$ from $X^{\mathrm{var}}$ whereas regression model II is more appropriate to summarise the relationship between $X^{\mathrm{var}}$ and $Y^{\mathrm{var}}$. Again, the particular case of the computation of ocean mineralization rates and ratios from field data falls within the requisites of the symmetric relationships as established by McArdle (2003) or regression model II as established by Warton et al. (2006). According to Prairie et al. (1995), using regression model I when the equation error is large can reveal significant relationships where none exists and vice versa or seriously bias the interpretation of the underlying natural relationship.

To avoid the controversy between models I and II, here we propose to revisit the geometric mean regression model by taking into account the relative uncertainties of the measurements of $X^{\mathrm{var}}$ and $Y^{\mathrm{var}}$, i.e. the measurement error, and their intrinsic relationship, i.e. the equation error. A generalised consensus least square regression model is used to fulfil the discontinuity between models I and II. The formulation is given in Appendix A1 and the estimation of weight factor in Appendix A2. Ready-to-use functions to install in MATLAB or Excel are also provided as Supplementary online material and explained in Appendix A3.

\section{Impact of mixing and mineralization on nutrients and oxygen distributions}

The relative contribution of mineralization and mixing on AOU, $\mathrm{N}, \mathrm{P}$ and $\mathrm{Si}$ can be quantified comparing the standard deviation (STD) of the residuals of the OMP model $(\triangle \mathrm{NC}=\mathrm{NC}-X \cdot A)$ with the STD of the OMP model $(X \cdot A), \mathrm{STD}_{\Delta} / \mathrm{STD}_{\mathrm{T}}$. This index was calculated within the SWT realms shown in Fig. 1 for N, P, Si and AOU (Table 4). For the case of Si, only the Central Water realms were considered since we have assumed that this nutrient behaved
Table 4

Contribution of biogeochemical over mixing processes on non-conservative properties. Standard deviation of the residuals, $\triangle \mathrm{NC}(=\mathrm{NC}-X \cdot A),\left(\mathrm{STD}_{\Delta}\right)$, divided by the standard deviation of the modelled, $X \cdot A,\left(\mathrm{STD}_{\mathrm{T}}\right)$, concentrations of the nonconservative parameters nitrate $(\mathrm{N})$, phosphate $(\mathrm{P})$, silicate $(\mathrm{Si})$ and apparent oxygen utilisation (AOU) obtained with the OMP analysis of the water mass realms depicted in Fig. 1. Number of samples in brackets.

\begin{tabular}{|c|c|c|c|c|}
\hline & $\mathrm{N}$ & $\mathrm{P}$ & AOU & $\mathrm{Si}$ \\
\hline \multicolumn{5}{|l|}{ A14 } \\
\hline SACW-E ${ }_{18}(54)$ & 0.78 & 0.78 & 0.81 & 0.96 \\
\hline$S A C W-E_{12}(63)$ & 0.61 & 0.64 & 0.72 & 0.86 \\
\hline SACW-T ${ }_{18}(58)$ & 0.63 & 0.62 & 1.14 & 1.49 \\
\hline SACW-T 12 (66) & 0.89 & 0.9 & 1.50 & 1.96 \\
\hline AAIW (414) & 1.12 & 1.11 & 1.31 & \\
\hline UCDW (147) & 0.35 & 0.37 & 0.83 & \\
\hline $\mathrm{NADW}_{4.6}(221)$ & 0.36 & 0.29 & 0.59 & \\
\hline $\mathrm{NADW}_{2}(963)$ & 0.38 & 0.33 & 0.62 & \\
\hline LCDW (115) & 0.20 & 0.24 & 0.39 & \\
\hline \multicolumn{5}{|l|}{$A 17$} \\
\hline $\mathrm{STMW}_{18}(17)$ & 0.60 & 0.58 & 0.91 & 0.94 \\
\hline SACW-T 18 (79) & 1.04 & 1.56 & 1.62 & 1.37 \\
\hline $\mathrm{EQ}_{13}(106)$ & 2.03 & 1.98 & 2.76 & 4.04 \\
\hline AAIW (527) & 2.33 & 2.22 & 2.43 & \\
\hline UCDW (194) & 0.44 & 0.51 & 0.73 & \\
\hline $\mathrm{NADW}_{4.6}(555)$ & 0.60 & 0.60 & 0.86 & \\
\hline $\mathrm{NADW}_{2}(1248)$ & 0.25 & 0.27 & 0.50 & \\
\hline LCDW (172) & 0.20 & 0.26 & 0.38 & \\
\hline $\mathrm{WSDW}_{-0.3}(637)$ & 0.39 & 0.47 & 0.61 & \\
\hline
\end{tabular}

conservatively in Intermediate, deep and bottom waters (Álvarez et al., this issue). The higher the index, the higher the contribution of mineralization processes to the variability of AOU or nutrient salts. The magnitude of the index depended mainly on two factors (Table 2 and Fig. 1): (i) the area occupied by each realm: the higher the area the higher the relative contribution of mineralization processes; and (ii) the archetypal depth range of the SWT: the shallower the higher the relative contribution of mineralization processes. It should be kept in mind that the depth range between 100 and 1000 dbar accounts for about $90 \%$ of the whole ocean respiration (Del Giorgio and Duarte, 2002) and that the respiration rate decreases exponentially with depth (Arístegui et al., 2003).

In general, the index was higher for AOU than for N or P (Table 4) since AOU is more sensitive to mineralization processes than inorganic nutrients. Water masses along the A17 line were more affected by mineralization than along the A14 line, which was $3200 \mathrm{~km}$ shorter. AAIW was the SWT most affected by mineralization. AAIW perfectly fulfils the two factors stated above: it laid around 900 dbar and occupied a large volume of both WOCE lines (Table 2 and Fig. 1). Regarding Si, its variability in the Central Water realms was highly determined by mineralization processes, especially in the $\mathrm{EQ}_{13}$ of the western basin, which moved from its formation area in the eastern South Atlantic transported by the South Equatorial Current.

\section{Impact of mixing and mineralization on the $\mathrm{N} / \mathrm{P}$ and $\mathrm{N} / \mathrm{Si}$ ratios}

The independent effects of mixing and local mineralization on the N/P and N/Si molar ratios can be assessed for the realm of each SWT by comparing the ratios calculated from: (i) OMP model concentrations $(X \cdot A)$, Table 1$),(\mathrm{N} / \mathrm{P})_{\mathrm{T}}$ and $(\mathrm{N} / \mathrm{Si})_{\mathrm{T}}$, and (ii) OMP residuals $(\Delta \mathrm{NC}=\mathrm{NC}-X \cdot A),(\mathrm{N} / \mathrm{P})_{\Delta}$ and $(\mathrm{N} / \mathrm{Si})_{\Delta}$. In order to compare with former studies, the ratios are also calculated with direct measured nutrients, $(\mathrm{N} / \mathrm{P})_{\mathrm{D}}$ and $(\mathrm{N} / \mathrm{Si})_{\mathrm{D}}$. For the case of the $\mathrm{N} / \mathrm{Si}$ ratios, only the Central Water realms were considered.

Nutrient ratios were calculated using the consensus linear regression model described in Section 2.5. Particularly, the regression calculated the slope and the intercept according to Eqs. A6 and A7 (Appendix A1), respectively, with a weight factor $\left(W_{\mathrm{X}}\right)$ 
according to Eq. A8 (Appendix A2) with no equation error and the sampling error $\left(\mathrm{er}_{\mathrm{X}}\right)$ was taken from the mean of the corresponding anomalies in the water realm. The weight factors $\left(W_{\mathrm{X}}\right)$ are shown in Table A1.

The $(\mathrm{N} / \mathrm{P})_{\mathrm{T}}$ ratios would account for the expected $\mathrm{N} / \mathrm{P}$ ratio if no other process except mixing of preformed SWT nutrient concentrations and basin scale mineralization processes from the formation to the study area affected the nutrient variability in the SWT realm. However, if local ventilation or mineralization processes in the study area do also affect nutrients variability, $(\mathrm{N} / \mathrm{P})_{\Delta}$ ratios would be significantly different from $(\mathrm{N} / \mathrm{P})_{\mathrm{T}}$ ratios. In this sense, a lower $\mathrm{N} / \mathrm{P}$ ratio would evidence the mineralization of fresher biogenic organic matter as organic phosphorous compounds are generally considered more labile than organic nitrogen compounds (e.g. Tegelaar et al., 1989; Middelburg et al., 1993; Boyd and Trull, 2007; Lønborg and Álvarez-Salgado, 2012). The ratios are shown in Table 5 along with the corresponding $T$-Student for the comparison of the slopes. Fig. 2 depicts the ratios summarised in Table 5.

Nutrient type ratios, $(\mathrm{N} / \mathrm{P})_{\mathrm{T}}$, in the SAO varied between 16 and 18 for the shallower Central Waters, decreased monotonically to

\section{Table 5}

Nitrate $(\mathrm{N})$ to phosphate $(\mathrm{P})$ ratios from the direct measurements, $(\mathrm{N} / \mathrm{P})_{\mathrm{D}}$; from the OMP model concentrations, obtained from $X \cdot A,(\mathrm{~N} / \mathrm{P})_{\mathrm{T}}$; and from the residuals of the OMP model, obtained from $\Delta \mathrm{NC}=\mathrm{NC}-X \cdot A,(\mathrm{~N} / \mathrm{P})_{\Delta}$. These ratios were obtained for the water mass realms depicted in Fig. 1, from the slopes of the consensus regression model. Slope \pm standard error and determination coefficient $\left(r^{2}\right)$ are presented. $T_{1}$ stands for the $T$-Student test comparing $(\mathrm{N} / \mathrm{P})_{\mathrm{D}}$ and $(\mathrm{N} / \mathrm{P})_{\mathrm{T}}$ and $T_{2}$ compares $(\mathrm{N} / \mathrm{P})_{\mathrm{T}}$ and $(\mathrm{N} / \mathrm{P})_{\Delta}$

\begin{tabular}{|c|c|c|c|c|c|}
\hline & $\begin{array}{l}(\mathrm{N} / \mathrm{P})_{\mathrm{D}} \\
r^{2}\end{array}$ & $\begin{array}{l}(\mathrm{N} / \mathrm{P})_{\mathrm{T}} \\
r^{2}\end{array}$ & $\begin{array}{l}(\mathrm{N} / \mathrm{P})_{\Delta} \\
r^{2}\end{array}$ & $\begin{array}{l}T_{1} \\
(\mathrm{D} \text { vs. } \mathrm{T})\end{array}$ & $\begin{array}{l}T_{2} \\
(\mathrm{~T} \text { vs. } \Delta)\end{array}$ \\
\hline \multicolumn{6}{|l|}{ A14 } \\
\hline $\mathrm{SACW}-\mathrm{E}_{18}$ & $\begin{array}{l}17.2 \pm 0.3 \\
0.984\end{array}$ & $\begin{array}{l}17.46 \pm 0.01 \\
1.000\end{array}$ & $\begin{array}{l}17.5 \pm 0.5 \\
0.966\end{array}$ & n.s. & n.s. \\
\hline SACW-E 12 & $\begin{array}{l}16.7 \pm 0.3 \\
0.983\end{array}$ & $\begin{array}{l}17.46 \pm 0.01 \\
1.000\end{array}$ & $\begin{array}{l}16.8 \pm 0.4 \\
0.957\end{array}$ & $* *$ & n.s. \\
\hline $\mathrm{SACW} \mathrm{T}_{18}$ & $\begin{array}{l}17.3 \pm 0.3 \\
0.978\end{array}$ & $\begin{array}{l}17.45 \pm 0.01 \\
1.000\end{array}$ & $\begin{array}{l}17.6 \pm 0.6 \\
0.934\end{array}$ & n.s. & n.s. \\
\hline $\mathrm{SACW}-\mathrm{T}_{12}$ & $\begin{array}{l}17.2 \pm 0.2 \\
0.995\end{array}$ & $\begin{array}{l}17.44 \pm 0.00 \\
1.000\end{array}$ & $\begin{array}{l}17.2 \pm 0.3 \\
0.983\end{array}$ & n.s. & n.s. \\
\hline AAIW & $\begin{array}{l}15.6 \pm 0.1 \\
0.986\end{array}$ & $\begin{array}{l}15.81 \pm 0.05 \\
0.996\end{array}$ & $\begin{array}{l}16.1 \pm 0.1 \\
0.980\end{array}$ & n.s. & ** \\
\hline UCDW & $\begin{array}{l}14.3 \pm 0.2 \\
0.979\end{array}$ & $\begin{array}{l}14.18 \pm 0.04 \\
0.999\end{array}$ & $\begin{array}{l}13.3 \pm 0.5 \\
0.810\end{array}$ & n.s. & n.s. \\
\hline $\mathrm{NADW}_{4.6}$ & $\begin{array}{l}13.6 \pm 0.1 \\
0.988\end{array}$ & $\begin{array}{l}14.08 \pm 0.03 \\
0.999\end{array}$ & $\begin{array}{l}12.8 \pm 0.3 \\
0.877\end{array}$ & $* * * *$ & ${ }^{* * * *}$ \\
\hline $\mathrm{NADW}_{2}$ & $\begin{array}{l}10.7 \pm 0.1 \\
0.930\end{array}$ & $\begin{array}{l}13.74 \pm 0.02 \\
0.998\end{array}$ & $\begin{array}{l}18.4 \pm 0.5 \\
0.417\end{array}$ & $* * * *$ & **** \\
\hline LCDW & $\begin{array}{l}14.5 \pm 0.2 \\
0.976\end{array}$ & $\begin{array}{l}14.15 \pm 0.02 \\
1.000\end{array}$ & $\begin{array}{l}11.8 \pm 0.7 \\
0.689\end{array}$ & n.s. & ${ }^{* * * *}$ \\
\hline A17 & & & & & \\
\hline $\mathrm{STMW}_{18}$ & $\begin{array}{l}16.9 \pm 0.5 \\
0.987\end{array}$ & $\begin{array}{l}17.29 \pm 0.1 \\
0.999\end{array}$ & $\begin{array}{l}17.8 \pm 0.5 \\
0.989\end{array}$ & n.s. & n.s. \\
\hline $\mathrm{SACW} \mathrm{T}_{18}$ & $\begin{array}{l}10.8 \pm 0.5 \\
0.868\end{array}$ & $\begin{array}{l}16.53 \pm 0.1 \\
0.996\end{array}$ & $\begin{array}{l}10.9 \pm 0.5 \\
0.858\end{array}$ & **** & ${ }^{* * * *}$ \\
\hline $\mathrm{EQ}_{13}$ & $\begin{array}{l}17.0 \pm 0.1 \\
0.995\end{array}$ & $\begin{array}{l}16.70 \pm 0.1 \\
0.995\end{array}$ & $\begin{array}{l}17.1 \pm 0.1 \\
0.995\end{array}$ & n.s. & * \\
\hline AAIW & $\begin{array}{l}15.7 \pm 0.1 \\
0.987\end{array}$ & $\begin{array}{l}15.23 \pm 0.06 \\
0.991\end{array}$ & $\begin{array}{l}16.0 \pm 0.1 \\
0.988\end{array}$ & $* * *$ & *** \\
\hline UCDW & $\begin{array}{l}13.3 \pm 0.2 \\
0.971\end{array}$ & $\begin{array}{l}13.86 \pm 0.04 \\
0.999\end{array}$ & $\begin{array}{l}11.8 \pm 0.3 \\
0.874\end{array}$ & $* * *$ & $* * *$ \\
\hline $\mathrm{NADW}_{4.6}$ & $\begin{array}{l}13.8 \pm 0.1 \\
0.987\end{array}$ & $\begin{array}{l}14.07 \pm 0.03 \\
0.998\end{array}$ & $\begin{array}{l}14.1 \pm 0.2 \\
0.916\end{array}$ & $* * * *$ & n.s. \\
\hline $\mathrm{NADW}_{2}$ & $\begin{array}{l}13.2 \pm 0.1 \\
0.958\end{array}$ & $\begin{array}{l}14.02 \pm 0.02 \\
0.998\end{array}$ & $\begin{array}{l}12.6 \pm 0.3 \\
0.515\end{array}$ & $* * *$ & $* * *$ \\
\hline LCDW & $\begin{array}{l}14.1 \pm 0.2 \\
0.972\end{array}$ & $\begin{array}{l}14.07 \pm 0.02 \\
1.000\end{array}$ & $\begin{array}{l}10.7 \pm 0.5 \\
0.686\end{array}$ & n.s. & *** \\
\hline WSDW $_{-0.3}$ & $\begin{array}{l}13.8 \pm 0.1 \\
0.931\end{array}$ & $\begin{array}{l}14.26 \pm 0.01 \\
0.999\end{array}$ & $\begin{array}{l}11.8 \pm 0.3 \\
0.703\end{array}$ & $* * * *$ & ${ }^{* * * *}$ \\
\hline
\end{tabular}

n.s.: no significant difference.

${ }^{*} p<0.05$.

$p<0.01$.

$p<0.005$ values between 15 and 16 at the AAIW level and to 14 at the UCDW level, and from there to the bottom they kept constant. Note that this pattern is opposite to the expected increase of the N/P ratio with depth if fresh P-rich sinking biogenic materials are mineralised at shallower levels. It indicates that the preformed N/P ratios at the site of formation of the SWT together with the mineralization of P-poor dissolved and suspended organic matter impinged on the $(\mathrm{N} / \mathrm{P})_{\mathrm{T}}$ profile more than the P-rich sinking organic matter. This basin scale pattern can be altered by the local mineralization of dissolved, suspended and sinking biogenic materials. In this sense, $(\mathrm{N} / \mathrm{P})_{\Delta}$ ratios were significantly lower than $(\mathrm{N} / \mathrm{P})_{\mathrm{T}}$ ratios in most cases in the western basin indicating a preferential mineralization of organic phosphorous at the local scale compared with the basin scale. Exceptions to this pattern were the STMW ${ }_{18}$, too fresh to detect any significant difference between type (basin scale) and residual (local scale) ratios, and the NADW 4.6 , where the intensity of local mineralization processes seemed to be very limited. The only intermediate water with $(\mathrm{N} / \mathrm{P})_{\Delta}$ higher than $(\mathrm{N} /$ $\mathrm{P})_{\mathrm{T}}$ was AAIW. Note that AAIW is formed in the Subantarctic Front region, sinking from the surface to about $900 \mathrm{dbar}$ north of the Subtropical Front and it extends all along the South Atlantic Ocean (Fig. 1) occupying a relatively large area (Table 2) within the mesopelagic zone, where high rates of organic matter mineralization are expected (Arístegui et al., 2003). Therefore, AAIW would integrate the mineralization of both fresh and aged organic matter; the fact that $(\mathrm{N} / \mathrm{P})_{\Delta}>(\mathrm{N} / \mathrm{P})_{\mathrm{T}}$ indicates that the mineralized material was mostly aged biogenic matter. It is also remarkable the low $(\mathrm{N} / \mathrm{P})_{\Delta}$ value obtained for SACW- $\mathrm{T}_{18}$ in the western basin, $10.9 \pm 0.5 \mathrm{~mol} \mathrm{~N}$ mol $\mathrm{P}^{-1}$, much lower than in the eastern basin, $17.6 \pm 0.6 \mathrm{~mol} \mathrm{~N}$ $\mathrm{mol} \mathrm{P} \mathrm{P}^{-1}$, closer to the formation area. It indicates that a relatively fresh biogenic material was mineralized in the SACW-T $\mathrm{T}_{18}$ realm while displacing from the eastern to the western basin. Another notable case occurred in the $\mathrm{NADW}_{2}$ realm: the $(\mathrm{N} / \mathrm{P})_{\mathrm{T}}$ values, $\sim 14 \mathrm{~mol} \mathrm{~N}$ mol $\mathrm{P}^{-1}$, were similar in both sections but the $(\mathrm{N} / \mathrm{P})_{\Delta}$ residual ratios were significantly higher is the eastern $\left(18.4 \pm 0.5 \mathrm{~mol} \mathrm{~N} \mathrm{~mol} \mathrm{P}^{-1}\right) \quad$ compared with the western $\left(12.6 \pm 0.3 \mathrm{~mol} \mathrm{~N} \mathrm{~mol} \mathrm{P}^{-1}\right)$ basin. This fact can be related to the general circulation of NADW in the South Atlantic (Álvarez et al., this issue): the main entry and transport route of NADW is along the western margin and only remnants derived from the Deep Western Boundary Current reach the eastern basin. Accordingly, a very aged material was mineralized in the $\mathrm{NADW}_{2}$ that reached the eastern basin. However, this result should be taken with caution because of the low $r^{2}$ for the $(\mathrm{N} / \mathrm{P})_{\Delta}$ ratio in the A14 NADW $\mathrm{N}_{2}$.

The same sort of analysis was performed for the Central Water $\mathrm{N} / \mathrm{Si}$ ratios (Table 6). Except for the Equatorial SACW of the eastern basin, the N/Si type values were higher than the residual ones, indicating that a silica-rich and/or nitrogen-poor biogenic material was mineralized there. Significant differences were found in the N/ Si residual ratios: with depth in the western basin and with latitude in the eastern basin. In the western basin, the deepest (378 dbar, Table 2 ) and coldest $\left(13^{\circ} \mathrm{C}\right.$ Table 2 in Álvarez et al., this issue) Central Water, $\mathrm{EQ}_{13}$, had the lowest $(\mathrm{N} / \mathrm{Si})_{\Delta}$ ratio, probably because of the frequent diatom blooms in the formation area, near Namibia (Berger and Wefer, 2002); the mineralization of this silica-rich biogenic material would explain the low ratio. In the case of the eastern basin, subtropical Central Waters presented a lower ratio than the equatorial ones. This fact could be related with the residence time of biogenic particles in each realm. Subequatorial Central Waters receive an important flux of silica-rich biogenic particles, formed during diatoms blooms from upwelled nutrients and rapidly sink as marine aggregates (Sarmiento and Gruber, 2006). The settling velocities of marine aggregates of tenths of meters per day (Asper, 1987) along with the limited depth range of these realms (Fig. 1) could explain the low silica mineralization and thus, the high $(\mathrm{N} / \mathrm{Si})_{\Delta}$ ratios. On the contrary, subtropical 

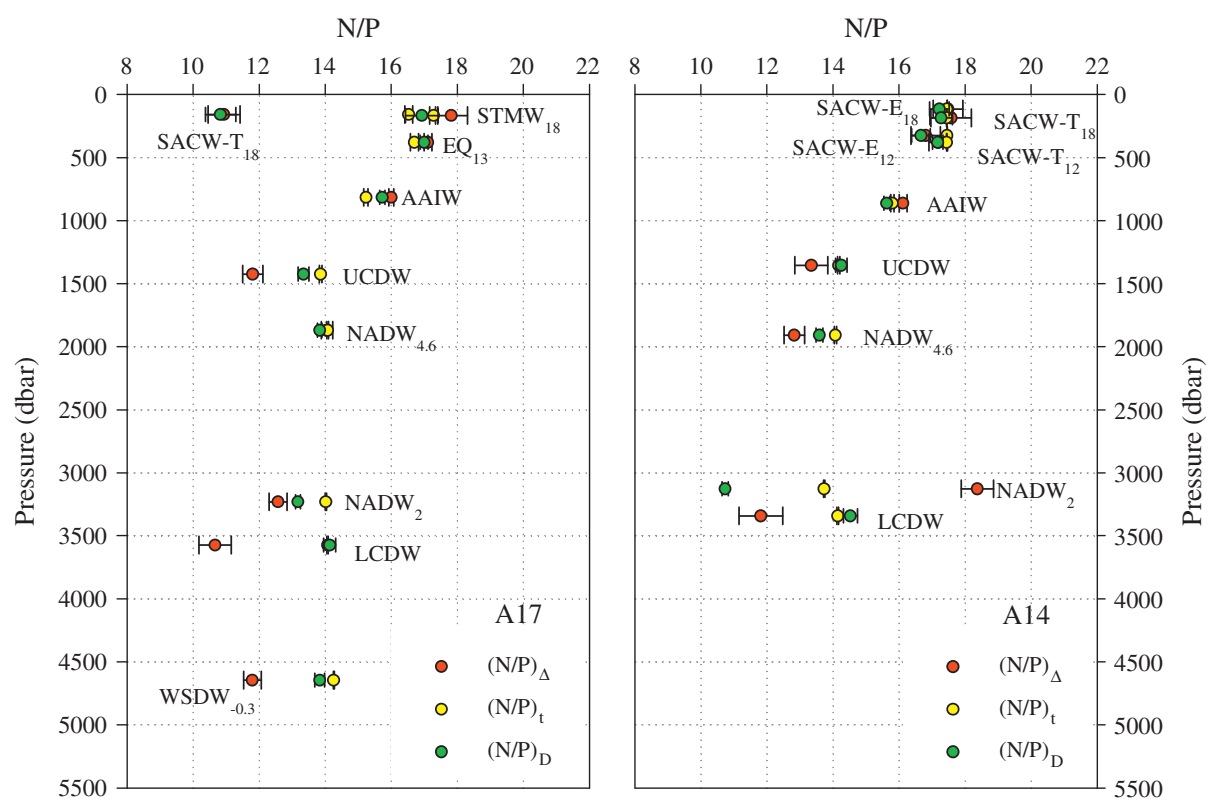

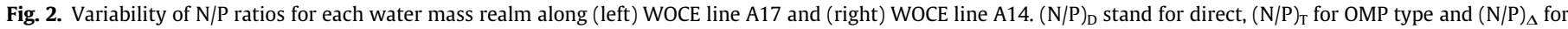
OMP residual ratios. OMP archetypal pressure of each water mass realm was taken from Table 2.

Table 6

Nitrate $(\mathrm{N})$ to silicate $(\mathrm{Si})$ ratios from the direct measurements, $(\mathrm{N} / \mathrm{Si})_{\mathrm{D}}$; from the OMP model concentrations, obtained from $X \cdot A,(\mathrm{~N} / \mathrm{Si})_{\mathrm{T}}$; and from the residuals of the OMP model, obtained from $\triangle \mathrm{NC}=\mathrm{NC}-X \cdot A,(\mathrm{~N} / \mathrm{Si})_{\Delta}$. Ratios were calculated for the Central Water mass realms depicted in Fig. 1, from the slopes of the consensus regression model. Slope \pm standard error and determination coefficient $\left(r^{2}\right)$ are presented. $T_{1}$ stands for the $T$-Student test comparing $(\mathrm{N} / \mathrm{Si})_{\mathrm{D}}$ and $(\mathrm{N} / \mathrm{Si})_{\mathrm{T}}$ and $T_{2}$ compares $(\mathrm{N} / \mathrm{Si})_{\mathrm{T}}$ and $(\mathrm{N} / \mathrm{Si})_{\Delta}$.

\begin{tabular}{|c|c|c|c|c|c|}
\hline & $\begin{array}{l}(\mathrm{N} / \mathrm{Si})_{\mathrm{D}} \\
r^{2}\end{array}$ & $\begin{array}{l}(\mathrm{N} / \mathrm{Si})_{\mathrm{T}} \\
r^{2}\end{array}$ & $\begin{array}{l}(\mathrm{N} / \mathrm{Si})_{\Delta} \\
r^{2}\end{array}$ & $\begin{array}{l}T_{1} \\
(\mathrm{D} \text { vs. T) }\end{array}$ & $\begin{array}{l}T_{2} \\
(\mathrm{~T} \text { vs. } \Delta)\end{array}$ \\
\hline \multicolumn{6}{|l|}{ A14 } \\
\hline SACW-E 18 & $\begin{array}{l}2.9 \pm 0.2 \\
0.800\end{array}$ & $\begin{array}{l}3.15 \pm 0.01 \\
1.000\end{array}$ & $\begin{array}{l}2.8 \pm 0.2 \\
0.637\end{array}$ & n.s. & n.s. \\
\hline SACW-E 12 & $\begin{array}{l}2.4 \pm 0.1 \\
0.783\end{array}$ & $\begin{array}{l}3.15 \pm 0.01 \\
1.000\end{array}$ & $\begin{array}{l}2.7 \pm 0.3 \\
0.472\end{array}$ & *** & n.s. \\
\hline $\mathrm{SACW} \mathrm{T}_{18}$ & $\begin{array}{l}3.6 \pm 0.3 \\
0.598\end{array}$ & $\begin{array}{l}4.83 \pm 0.2 \\
0.942\end{array}$ & $\begin{array}{l}2.0 \pm 0.1 \\
0.719\end{array}$ & **** & $* * *$ \\
\hline SACW-T 12 & $\begin{array}{l}2.8 \pm 0.2 \\
0.781\end{array}$ & $\begin{array}{l}4.59 \pm 0.1 \\
0.953\end{array}$ & $\begin{array}{l}2.1 \pm 0.2 \\
0.580\end{array}$ & **** & $* * *$ \\
\hline$A 17$ & & & & & \\
\hline $\mathrm{STMW}_{18}$ & $\begin{array}{l}4.0 \pm 0.9 \\
0.278\end{array}$ & $\begin{array}{l}4.66 \pm 0.05 \\
0.999\end{array}$ & $\begin{array}{l}3.2 \pm 0.5 \\
0.607\end{array}$ & n.s. & * \\
\hline $\mathrm{SACW} \mathrm{T}_{18}$ & $\begin{array}{l}3.5 \pm 0.2 \\
0.713\end{array}$ & $\begin{array}{l}4.23 \pm 0.06 \\
0.987\end{array}$ & $\begin{array}{l}3.3 \pm 0.2 \\
0.745\end{array}$ & $* * * *$ & $* * *$ \\
\hline $\mathrm{EQ}_{13}$ & $\begin{array}{l}2.4 \pm 0.1 \\
0.932\end{array}$ & $\begin{array}{l}4.46 \pm 0.04 \\
0.990\end{array}$ & $\begin{array}{l}2.3 \pm 0.1 \\
0.898\end{array}$ & **** & $* * *$ \\
\hline
\end{tabular}

n.s.: no significant difference.

${ }^{* *} p<0.01$.

${ }^{*} p<0.05$.

*** $p<0.005$.

Central Waters receive a lower influx of particles (Sarmiento and Gruber, 2006) which sink slower (Clegg and Whitfield, 1990) than in the subequatorial area. Additionally, subtropical waters occupy a wider depth range, increasing the residence time and, consequently, the extension of biogenic silica mineralization that could contribute to explain the lower $(\mathrm{N} / \mathrm{Si})_{\Delta}$ ratios obtained.

\section{Quality of the mineralised biogenic material}

The main groups of biomolecules ordered by decreasing lability are phosphorous compounds, proteins, carbohydrates and lipids.
This lability scale translates into a preferential mineralization of biogenic $\mathrm{P}$ against $\mathrm{N}$ and of $\mathrm{N}$ against $\mathrm{C}$, i.e. an element fractionation during biogenic matter mineralization (Tegelaar et al., 1989; Middelburg et al., 1993; Shaffer et al., 1999; Brea et al., 2004; Álvarez-Salgado et al. 2006; Boyd and Trull, 2007; Lønborg et al., 2009).

The former section presented and discussed the diverse N/P/Si ratios in the water mass realms of the South Atlantic Ocean, pointing to the existence of fractionation during biogenic matter mineralization. Although inorganic carbon system variables were measured in WOCE lines A14 and A17 (Rios et al., 2003, 2010), C/ $\mathrm{N} / \mathrm{P}$ ratios have not been calculated in this work because inorganic carbon stocks in the ocean are not only affected by biogenic inorganic and organic carbon mineralization but also by the entry of anthropogenic carbon $\left(\mathrm{C}_{\mathrm{ANT}}\right)$ accumulated in the atmosphere (Sabine et al., 2004). Widely used back-calculation methods to estimate $C_{\mathrm{ANT}}$ from measured carbon system variables require an a priori definition of the $R_{\mathrm{C}}(\mathrm{AOU} / \mathrm{C})$ ratio (Gruber et al., 1996; Touratier and Goyet, 2004a,b; Touratier et al., 2007). In order to avoid setting an a priori $R_{\mathrm{C}}$ value, we propose to estimate the $R_{\mathrm{N}}$ $(\mathrm{AOU} / \mathrm{N}), R_{\mathrm{P}}(\mathrm{AOU} / \mathrm{P}), R_{\mathrm{C}}$ and $\mathrm{C} / \mathrm{N}$ molar ratios of the mineralised biogenic matter following these steps:

(i) To take the $R_{\mathrm{P}}$ and $R_{\mathrm{N}}$ ratios obtained from the consensus slopes of the linear regressions of $\Delta A O U-\Delta P$ and $\Delta A O U-\Delta N$ within each water mass realm in the western and eastern basins (Fig. 1). Particularly, the consensus slopes were calculated according to Eq. A6 (Appendix A1) using a weight factor $\left(W_{\mathrm{X}}\right)$ estimated according to Eq. A8 (Appendix A2, Table A1) with no equation error and the sampling error $\left(e r_{X}\right)$ taken from the mean of the corresponding residuals in the water mass realm.

(ii) To apply the stoichiometric model described in Section 2.3 for estimating the proportions of proteins (Prt), phosphorous compounds (Pho), lipids (Lip) and carbohydrates ( $\mathrm{Cbh}$ ) that are compatible with the mineralization of at least $10 \%$ of Lip or Cbh (Álvarez-Salgado et al., 2006).

(iii) To obtain the range of compatible $R_{\mathrm{C}}$ and $\mathrm{C} / \mathrm{N}$ molar ratios from the range of biochemical compositions. 
The $R_{\mathrm{N}}$ and $R_{\mathrm{P}}$ ratios together with the range of compatible biochemical composition of the mineralised material and the resulting $\mathrm{C} / \mathrm{N}$ molar ratios are shown in Table 7 for each water mass realm and basin. Considering an average formula for the organic matter composition of $\mathrm{C}_{106} \mathrm{H}_{175} \mathrm{O}_{42} \mathrm{~N}_{16} \mathrm{P}$ (Anderson, 1995; Fraga et al., 1998) the largest differences between the calculated $\mathrm{R}_{\mathrm{N}}$ with the nominal value of 9.38 were obtained in the Central Water realms of both the western and eastern basin (Table 7). Proteins were preferentially mineralised in these realms (Table 7); on average, 54\% of the mineralized biogenic organic materials were proteins. By contrast, in the case of the Intermediate and deep waters, the average contribution of proteins reduced to $46 \%$ and $41 \%$, respectively (Table 7 ). On the contrary, the mineralization of phosphorus compounds did not exhibit a clear trend with depth but changed on basis of the relative position of each SWT in relation to the formation area.

The variability of the $\mathrm{C} / \mathrm{N}$ molar ratios of organic matter mineralization in both sections was quite similar. In general, it increased with depth, with no significant differences between the western and eastern basins (Fig. 3 and Table 7). Withdrawing the $\mathrm{NADW}_{2}$ and $W_{S D W}-0.3$ results, the relationship between the $C / N$ ratio and the archetypal pressure ( $p$, positive, in dbar) of each water mass, was:

$\mathrm{C} / \mathrm{N}=6.1( \pm 0.2)+0.5( \pm 0.2) \cdot p / 1000 \quad r^{2}=0.40$,

$p<0.00001, \quad n=13$

For a pressure range 126-3300 dbar, which could be compared with the equation $\mathrm{C} / \mathrm{N}=7.9-0.5 \cdot(Z / 1000)$ (depth range $275-3220 \mathrm{~m}$, negative, $n=123$ ) obtained by Schneider et al. (2003) from a compilation of particulate material retained in sediment traps in the SAO. Our equation reflects the composition of the mineralised organic material, either dissolved or particulate, while the second equation reflects the depth dependence of the remaining particulate material. Despite the very different space coverage of the two data sets and approaches, the $\mathrm{C} / \mathrm{N}$ ratio of the mineralized and remaining particulate organic mater seems to increase with depth at the same rate, indicating a $\mathrm{C}$ enrichment in the remaining particulate material and a faster recycling of $\mathrm{C}$ over $\mathrm{N}$ in the mineralized, dissolved or particulate, material. In this sense, Hopkinson and Vallino (2005) reported that although the C:N:P stoichiometry of DOM mineralization is lower than for the bulk DOM, it is greater than the Redfield ratio. The products of early degradation of organic material exported from the mixed layer presented a $\mathrm{C} / \mathrm{N}$ ratio of $6.1 \pm 0.2$ (origin intercept of Eq. (11)) that is closer to the nominal Redfield value of 6.6 than the value of 7.9 reported by Schneider et al. (2003). Therefore, contrary to Hopkinson and Vallino (2005), it looks like recycling of dissolved organic matter and fast sinking particles in the epipelagic layer occurred following the Redfield's stoichiometry while particulate organic matter caught in sediment traps was significantly enriched in $\mathrm{C}$ over $\mathrm{N}$.

Our results support the hypothesis of the existence of fractionation during the mineralization of biogenic matter. The model by Suess and Muller (1980) proposed that sinking organic matter experiences a fractionation with depth of its composition, and therefore, $\mathrm{N}$ and $\mathrm{P}$ are mineralized faster than $\mathrm{C}$. The studies by Minster and Boulahdid (1987) and Boulahdid and Minster (1989)

Table 7

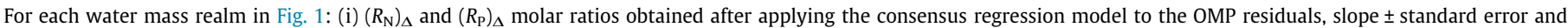

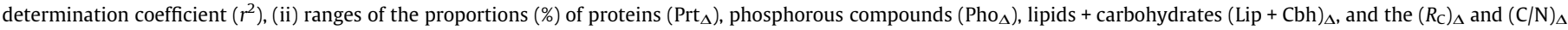
molar mineralization ratios compatible with the stoichiometric model presented in Section 2.3.

\begin{tabular}{|c|c|c|c|c|c|c|c|}
\hline & $\left(R_{\mathrm{N}}\right)_{\Delta}$ & $\left(R_{\mathrm{P}}\right)_{\Delta}$ & $(\% \operatorname{Prt})_{\Delta}$ & $(\% \mathrm{Pho})_{\Delta}$ & $(\% \text { Lip }+ \text { Cbh })_{\Delta}$ & $\left(R_{\mathrm{C}}\right)_{\Delta}$ & $(\mathrm{C} / \mathrm{N})_{\Delta}$ \\
\hline \multicolumn{8}{|l|}{ A14 } \\
\hline \multirow[t]{2}{*}{ SACW-E $E_{18}$} & $8.0 \pm 0.2$ & $140 \pm 5$ & [52.2-61.5] & [11.9-14.0] & [35.9-24.5] & [1.40-1.49] & [5.73-5.38] \\
\hline & 0.970 & 0.941 & & & & & \\
\hline \multirow[t]{2}{*}{$\mathrm{SACW}-\mathrm{E}_{12}$} & $8.9 \pm 0.2$ & $150 \pm 5$ & [44.2-55.7] & [10.6-13.3] & [45.2-30.9] & [1.35-1.47] & [6.64-6.07] \\
\hline & 0.966 & 0.931 & & & & & \\
\hline \multirow[t]{2}{*}{$\mathrm{SACW} \mathrm{T}_{18}$} & $8.4 \pm 0.8$ & $147 \pm 12$ & [48.2-58.8] & [10.6-13.3] & [45.2-30.9] & [1.35-1.47] & [6.64-6.07] \\
\hline & 0.598 & 0.639 & & & & & \\
\hline \multirow[t]{2}{*}{$\mathrm{SACW}-\mathrm{T}_{12}$} & $8.2 \pm 0.3$ & $141 \pm 6$ & [50.3-60.2] & [11.7-14.0] & [38.0-25.8] & [1.38-1.49] & [5.92-5.51] \\
\hline & 0.895 & 0.903 & & & & & \\
\hline \multirow[t]{2}{*}{ AAIW } & $9.4 \pm 0.0$ & $152 \pm 1$ & [40.8-52.9] & [10.2-13.3] & [49.0-33.8] & [1.32-1.47] & [7.12-6.43] \\
\hline & 0.998 & 0.985 & & & & & \\
\hline \multirow[t]{2}{*}{ UCDW } & $9.5 \pm 0.1$ & $127 \pm 4$ & [38.6-50.2] & [12.1-15.8] & [49.3-34.0] & [1.32-1.31] & [7.21-7.51] \\
\hline & 0.978 & 0.829 & & & & & \\
\hline \multirow[t]{2}{*}{$\mathrm{NADW}_{4.6}$} & $9.8 \pm 0.2$ & $126 \pm 3$ & [36.6-48.4] & [12.0-15.9] & [51.4-35.7] & [1.31-1.46] & [7.51-6.74] \\
\hline & 0.940 & 0.898 & & & & & \\
\hline \multirow[t]{2}{*}{$\mathrm{NADW}_{2}$} & $11.4 \pm 0.1$ & $206 \pm 5$ & [32.5-46.2] & [7.1-10.1] & [60.4-43.6] & [1.26-1.45] & [9.02-7.87] \\
\hline & 0.869 & 0.450 & & & & & \\
\hline \multirow[t]{2}{*}{ LCDW } & $9.8 \pm 0.4$ & $119 \pm 5$ & [35.9-47.5] & [12.8-16.9] & [51.3-35.6] & [1.31-1.46] & [7.52-6.75] \\
\hline & 0.814 & 0.837 & & & & & \\
\hline \multicolumn{8}{|l|}{ A17 } \\
\hline \multirow[t]{2}{*}{$\mathrm{STMW}_{18}$} & $8.7 \pm 0.3$ & $155 \pm 5$ & [46.6-57.8] & [10.4-12.9] & [43.0-29.3] & [1.36-1.48] & [6.39-5.87] \\
\hline & 0.978 & 0.982 & & & & & \\
\hline \multirow[t]{2}{*}{$\mathrm{SACW}-\mathrm{T}_{18}$} & $9.6 \pm 0.4$ & $105 \pm 3$ & [36.0-47.7] & [14.5-19.2] & [49.5-33.1] & [1.32-1.47] & [7.31-6.55] \\
\hline & 0.858 & 0.920 & & & & & \\
\hline \multirow[t]{2}{*}{$\mathrm{EQ}_{13}$} & $7.9 \pm 0.1$ & $136 \pm 2$ & [52.5-61.6] & [14.5-19.2] & [49.5-33.1] & [1.32-1.47] & [7.31-6.55] \\
\hline & 0.978 & 0.977 & & & & & \\
\hline \multirow[t]{2}{*}{ AAIW } & $9.8 \pm 0.0$ & $157 \pm 1$ & [38.7-51.2] & [9.8-12.9] & [51.5-35.8] & [1.31-1.46] & [7.47-6.70] \\
\hline & 0.996 & 0.990 & & & & & \\
\hline \multirow[t]{2}{*}{ UCDW } & $10.7 \pm 0.1$ & $126 \pm 3$ & [32.2-44.2] & [11.7-16.1] & [56.1-39.7] & [1.28-1.45] & [8.32-7.35] \\
\hline & 0.972 & 0.905 & & & & & \\
\hline \multirow[t]{2}{*}{$\mathrm{NADW}_{4.6}$} & $9.5 \pm 0.1$ & $134 \pm 1$ & [39.2-50.9] & [11.5-15.0] & [49.2-34.1] & [1.32-1.26] & [7.19-9.30] \\
\hline & 0.937 & 0.956 & & & & & \\
\hline \multirow[t]{2}{*}{$\mathrm{NADW}_{2}$} & $11.7 \pm 0.2$ & $148 \pm 2$ & [29.2-41.8] & [9.8-14.0] & [61.0-44.3] & [1.26-1.44] & [9.30-8.10] \\
\hline & 0.699 & 0.812 & & & & & \\
\hline \multirow[t]{2}{*}{ LCDW } & $10.1 \pm 0.4$ & $109 \pm 4$ & [33.5-44.7] & [13.7-18.4] & [52.8-36.9] & [1.30-1.46] & [7.79-6.95] \\
\hline & 0.719 & 0.789 & & & & & \\
\hline \multirow[t]{2}{*}{ WSDW-0.3 } & $9.3 \pm 0.2$ & $110 \pm 2$ & [38.5-49.4] & [14.0-18.0] & [47.5-32.7] & [1.33-1.47] & [7.00-6.35] \\
\hline & 0.756 & 0.794 & & & & & \\
\hline
\end{tabular}



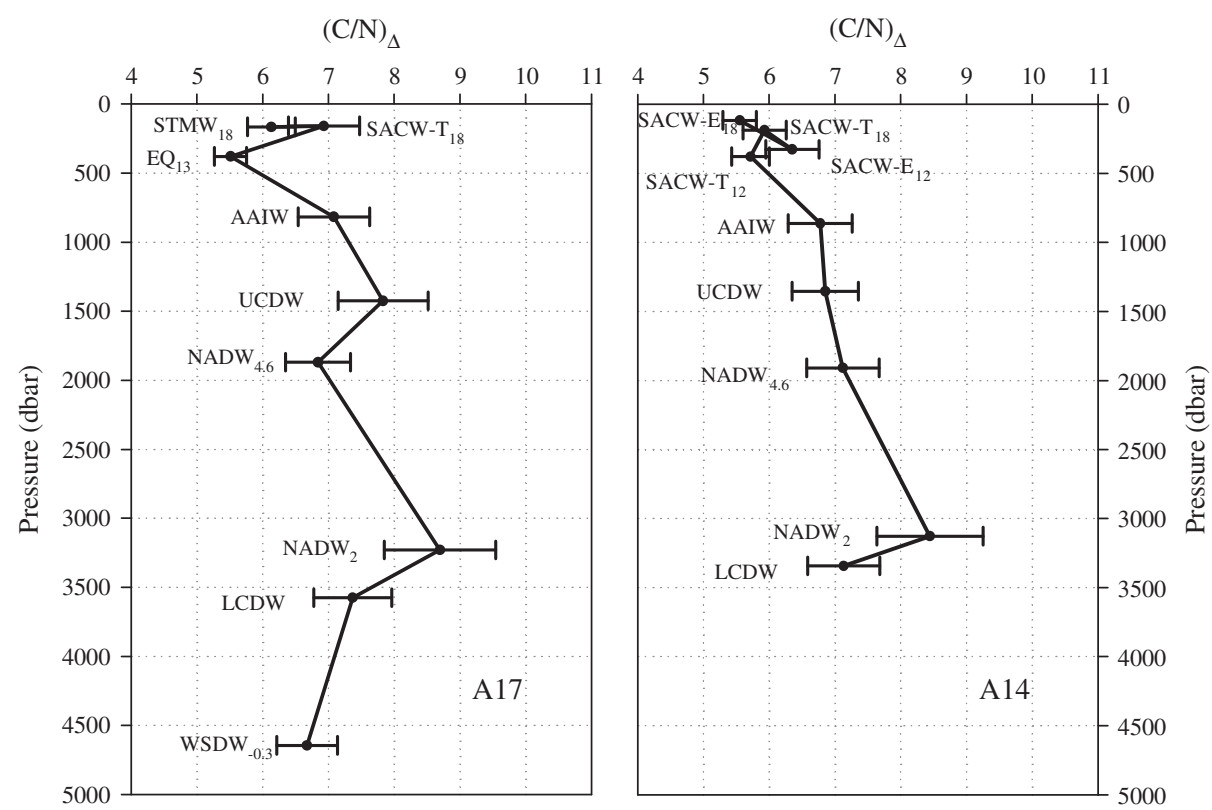

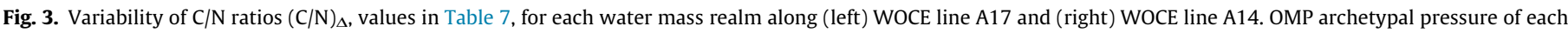
water mass realm was taken from Table 2.

about the variability of the $R_{\mathrm{P}}$ ratio along isopycnal surfaces also pointed to the existence of fractionation. More recent studies about fractionation using inorganic nutrient distributions were done by Shaffer et al. (1999), Li et al. (2000) and Li and Peng (2002). On the contrary, authors such as Broecker et al. (1985), Peng and Broecker (1987) and Anderson and Sarmiento (1994) support that mineralization ratios kept constant with depth and basin.

Other authors have proposed an alternative explanation for the variability of the $A O U / C / N / P$ ratios within the ocean. For example, $\mathrm{Li}$ and Peng (2002) detected changes in the ratios of deep water masses during its transit following the conveyor belt from the North Atlantic to the North Pacific. The ratios given for the North Pacific, AOU/C/N/P: 162/124/13/1, would be due to denitrification processes in microenvironments formed within falling particles. The results given by Li and Peng (2002) for other basins (Atlantic, Indian and Antarctic) are not compatible with the stoichiometric model of Fraga et al. (1998), as they produce negative proportions of Pho, Prt, Lip or Cbh (see next section). Other theories considered the anthropogenic effect on biogeochemical cycles, mainly in the quality and quantity of the material exported from the euphotic zone (Pahlow and Riebesell, 2000). Gruber et al. (2000) proposed that human activities can alter the water mass characteristics in the formation areas. Zhang et al. (2000) questioned the results of Pahlow and Riebesell (2000) because of inconsistencies in the raw inorganic nutrient data, which are often affected by bias due to the lack of use of reference materials (Gouretski and Jancke, 2001; Tanhua et al., 2010).

\section{Reviewing the stoichiometry of biogenic matter mineralization in the World Ocean}

Additionally, we have performed a literature review of $\mathrm{AOU} / \mathrm{C} /$ $\mathrm{N} / \mathrm{P}$ ratios estimated from inorganic nutrient, dissolved oxygen and inorganic carbon distributions in the oceans (Table 8). The ratios were evaluated considering the stoichiometric model presented in Section 2.3. Ratios yielding negative percentages of proteins, phosphorous compounds, lipids and/or carbohydrates are considered incompatible with the model. Assuming consistent data bases, the reasons to explain incompatible ratios are: (i) the separation of mixing from mineralization processes in the distribution of chemical variables can be incorrect due to an erroneous definition of the source water types or the number of them considered; (ii) the input of anthropogenic carbon in upper and intermediate waters, or even deep waters in the North Atlantic (Gruber et al., 1996), alters the residuals in inorganic carbon distribution; (iii) most of the works only consider mineralization processes occurring in oxygenated conditions, but others occur in suboxic or anoxic conditions.

\section{Lability of the mineralized biogenic material}

Following Karstensen and Tomczak (1998), we estimate OURs relying on the OMP results. We proceeded as follows: (i) the water mass realms were identified; (ii) the effect of mixing, either horizontal/vertical or isopycnal/diapycnal in the AOU and apparent age variability was separated from mineralization processes (Brea et al., 2004; Carlson et al., 2010); (iii) we restricted the age estimate to values younger than 35 years, corresponding to waters formed between 1960 and 1995 where the atmospheric CFC-11 increase was practically linear and direct CFC-11 apparent ages would be minimally affected by mixing of end-members with contrasting CFC-11 values (Doney and Bullister, 1997), (iv) the slope between AOU and $\tau$, OUR, took into account the error on both variables. Particularly, the consensus slopes were calculated using a weight factor estimated according to Eq. A8 (Appendix A2) with no equation error and the sampling error taken from the mean of the corresponding residuals in the water mass domain. Weights vary between 0.55 and 0.71 .

The OUR values for each water mass realm (Fig. 1) are shown in Table 9. In general, OURs were higher along WOCE line A14 as it crossed areas with larger sinking fluxes of biogenic organic matter. for example the Benguela/Namibia upwelling systems (Usbeck et al., 2003). To the best of our knowledge, except for Brea et al. (2004) and Warner and Weiss (1992), there are no other publications reporting mineralization rates in the SAO. The range of values that we found within the Central Water realms varied between 6.3 and $18 \mu \mathrm{mol} \mathrm{O} \mathrm{kg}^{-1} \mathrm{yr}^{-1}$, comparable to those found in thermocline waters of the North Atlantic (Sarmiento et al., 1990; Doney 
Table 8

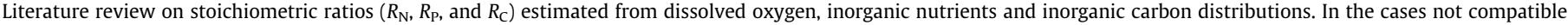

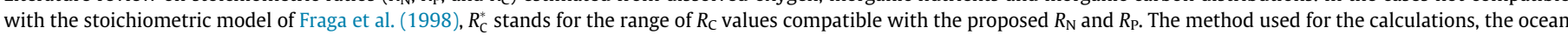

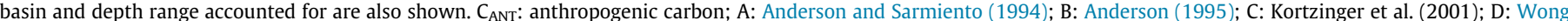

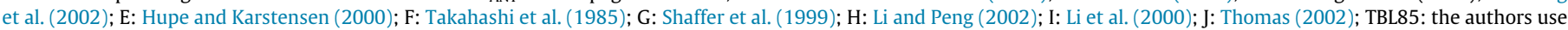
the method by Takahashi et al. (1985); MB87: the authors use the method Minster and Boulahdid (1987).

\begin{tabular}{|c|c|c|c|c|c|c|}
\hline$R_{\mathrm{N}}$ & $R_{\mathrm{P}}$ & $R_{\mathrm{C}}$ & $R_{\mathrm{C}}^{*}$ & Ref. & Method & Ocean/depth \\
\hline 10.6 & 170 & 1.45 & & A2 & Neutral surfaces & Global/400 m \\
\hline 14.2 & 170 & 1.45 & {$[1.21,1.43]$} & A3 & Neutral surfaces & Global/1000-3000 m \\
\hline 11.3 & 170 & 1.45 & & A4 & Neutral surfaces & Global/4000 m \\
\hline 9.4 & 150 & 1.42 & & $\mathrm{~B}$ & Biomolecules composition & Mean \\
\hline 9.4 & 165 & 1.34 & & $\mathrm{C} 1$ & Isopycnals & NE Atlantic/200-900 m \\
\hline 10.0 & 164 & 1.32 & & $\mathrm{C} 2$ & Isopycnals/TBL85 $-\mathrm{C}_{\mathrm{ANT}}$ & NE Atlantic/200-900 m \\
\hline 9.3 & 151 & 1.78 & {$[1.33,1.47]$} & $\mathrm{C} 3$ & Isopycnals/TBL85 $+\mathrm{C}_{\mathrm{ANT}}$ & NE Atlantic/200-900 m \\
\hline 8.9 & 166 & 1.36 & & $\mathrm{C} 4$ & Isopycnals/MB87 $-\mathrm{C}_{\mathrm{ANT}}$ & NE Atlantic/200-900 m \\
\hline 9.2 & 170 & 1.72 & {$[1.33,1.47]$} & $\mathrm{C} 5$ & Isopycnals/MB87 $+\mathrm{C}_{\mathrm{ANT}}$ & NE Atlantic/200-900 m \\
\hline 10.3 & 171 & 1.58 & {$[1.29,1.46]$} & $\mathrm{D}$ & Sediment traps & NE Pacific/0-1000 m \\
\hline 9.7 & 139 & 1.54 & {$[1.31,1.46]$} & E1 & Extended OMP & Global/550-1200 m \\
\hline 10.2 & 152 & 1.42 & & E2 & Extended OMP & Global/1200-2000 m \\
\hline 10.3 & 158 & 1.24 & {$[1.29,1.46]$} & E3 & Extended OMP & Global/2000-4500 m \\
\hline 10.8 & 172 & 1.41 & & $\mathrm{~F}$ & Isopycnals & Atlantic-Indian/thermocline \\
\hline 9.3 & 140 & 1.40 & & G1 & Neutral surfaces & Global/750 m \\
\hline 14.2 & 170 & 1.30 & & G2 & Neutral surfaces & Global/1500 m \\
\hline 8.6 & 137 & 1.88 & {$[1.36,1.48]$} & $\mathrm{H} 1$ & Inverse method & North Atlantic/whole column \\
\hline 8.9 & 133 & 1.66 & {$[1.35,1.47]$} & $\mathrm{H} 2$ & Inverse method & Antarct. Circump. Current/whole column \\
\hline 13.0 & 130 & 1.38 & & H3 & Inverse method & Equatorial Indian/whole column \\
\hline 12.5 & 162 & 1.30 & & $\mathrm{H} 4$ & Inverse method & North Pacific/whole column \\
\hline 13.1 & 170 & 1.26 & & $\mathrm{I} 1$ & Inverse method & ALOHA/whole column \\
\hline 13.0 & 168 & 1.62 & {$[1.23,1.43]$} & I2 & Isopycnal $\sigma 4=45.86$ & Deep Pacific \\
\hline 12.8 & 171 & 1.18 & {$[1.23,1.43]$} & I3 & Isopycnal $\sigma 4=45.94$ & Deep Indian \\
\hline 11.0 & 178 & 1.63 & {$[1.27,1.45]$} & 14 & Isopycnal $\sigma \theta=27.20$ & Indian \\
\hline 10.1 & 171 & 1.84 & {$[1.30,1.46]$} & I5 & Isopycnal $\sigma \theta=27.20$ & Atlantic \\
\hline 8.9 & 134 & 2.00 & {$[1.35,1.47]$} & $\mathrm{J} 1$ & Surface $-\sigma \theta=27.7$ & Deep North Atlantic \\
\hline 9.4 & 130 & 0.85 & {$[1.32,1.47]$} & $\mathrm{J} 2$ & $\sigma \theta=27.7$-bottom & Deep North Atlantic \\
\hline 9.2 & 131 & 1.05 & {$[1.33,1.47]$} & $\mathrm{J} 3$ & Whole column & Deep North Atlantic \\
\hline
\end{tabular}

Table 9

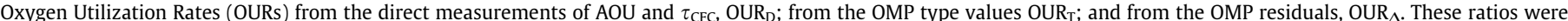

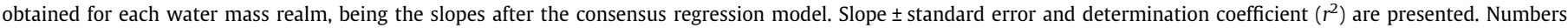

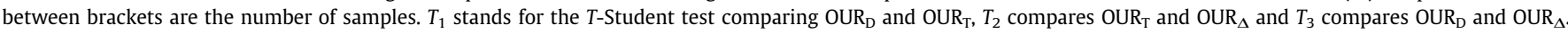

\begin{tabular}{|c|c|c|c|c|c|c|}
\hline & $\mathrm{OUR}_{\mathrm{D}}$ & OUR $_{T}$ & $\mathrm{OUR}_{\Delta}$ & $T_{1}(\mathrm{D}$ vs. $\mathrm{T})$ & $T_{2}(\mathrm{~T}$ vs. $\Delta)$ & $T_{3}(\mathrm{D}$ vs. $\Delta)$ \\
\hline \multicolumn{7}{|l|}{$A 14$} \\
\hline \multirow[t]{2}{*}{ SACW-E ${ }_{18}(52)$} & $8.7 \pm 0.3$ & $7.30 \pm 0.01$ & $7.5 \pm 0.4$ & $* * *$ & n.s. & * \\
\hline & 0.935 & 1.000 & 0.874 & & & \\
\hline \multirow[t]{2}{*}{ SACW-E ${ }_{12}(55)$} & $10.0 \pm 0.7$ & $7.30 \pm 0.01$ & $7.8 \pm 0.7$ & $* * *$ & n.s. & * \\
\hline & 0.744 & 1.000 & 0.621 & & & \\
\hline \multirow[t]{2}{*}{ SACW-T 18 (54) } & $17.5 \pm 1.0$ & $8.13 \pm 0.03$ & $13.5 \pm 1.6$ & $* * *$ & $* * *$ & * \\
\hline & 0.844 & 0.999 & 0.351 & & & \\
\hline \multirow[t]{2}{*}{ SACW-T 12 (60) } & $10.4 \pm 0.7$ & $8.23 \pm 0.08$ & $12.1 \pm 0.9$ & $* * *$ & $* * *$ & n.s. \\
\hline & 0.737 & 0.994 & 0.654 & & & \\
\hline \multirow[t]{2}{*}{ AAIW(287) } & $5.0 \pm 0.1$ & $3.27 \pm 0.05$ & $6.3 \pm 0.2$ & $* * *$ & $* * *$ & $* * *$ \\
\hline & 0.917 & 0.937 & 0.788 & & & \\
\hline \multicolumn{7}{|l|}{$A 17$} \\
\hline \multirow[t]{2}{*}{$\mathrm{STMW}_{18}(16)$} & $6.5 \pm 1.3$ & $8.3 \pm 0.2$ & $10.7 \pm 0.8$ & n.s. & ** & * \\
\hline & 0.54 & 0.994 & 0.930 & & & \\
\hline \multirow[t]{2}{*}{ SACW-T 18 (42) } & $6.7 \pm 0.6$ & $8.1 \pm 0.2$ & $8.5 \pm 0.8$ & * & n.s. & n.s. \\
\hline & 0.690 & 0.966 & 0.623 & & & \\
\hline \multirow[t]{2}{*}{$\mathrm{EQ}_{13}(68)$} & $6.3 \pm 0.4$ & $7.4 \pm 0.2$ & $10.1 \pm 0.9$ & * & $* * *$ & $* * *$ \\
\hline & 0.763 & 0.958 & 0.550 & & & \\
\hline \multirow[t]{2}{*}{ AAIW (431) } & $4.5 \pm 0.1$ & $3.5 \pm 0.1$ & $5.0 \pm 0.1$ & $* * *$ & $* * *$ & $* * *$ \\
\hline & 0.916 & 0.878 & 0.841 & & & \\
\hline
\end{tabular}

n.s.: no significant difference. Units are $\mu \mathrm{mol} \mathrm{kg} \mathrm{kg}^{-1}$.

${ }^{*} p<0.05$.

** $p<0.01$.

$p<0.005$

and Bullister, 1992; Jenkins, 1998) and South Indian Ocean (Karstensen and Tomczak, 1998). The range of OUR values within the AAIW realm was 3.3-6.3 $\mu \mathrm{mol} \mathrm{O} \mathrm{kg}^{-1} \mathrm{yr}^{-1}$, also comparable to the $2.7 \pm 2.0 \mu \mathrm{mol} \mathrm{O} \mathrm{kg}^{-1} \mathrm{yr}^{-1}$ proposed by Warner and Weiss (1992) using a one dimensional advective-diffusive model.

In most cases $\mathrm{OUR}_{\mathrm{D}}, \mathrm{OUR}_{\mathrm{T}}$ and $\mathrm{OUR}_{\Delta}$ values were significantly different among them (see $T$-tests in Table 9). Except for the Equa-

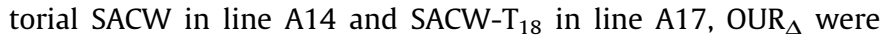
higher than OUR $_{\mathrm{T}}$ (Table 9 and Fig. 4), indicating that mineralization processes enhanced oxygen consumption once the relative contribution of each water mass type or characteristic OUR value when it enters the South Atlantic basin were accounted for. The

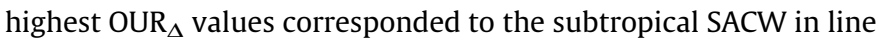
A14 followed by STMW ${ }_{18}$ and $\mathrm{EQ}_{13}$ in line A17. Oxygen consump- 
tion should be a function of the vertical and/or lateral input of organic matter and the residence time of this organic matter in the water mass realm. The equatorial and subequatorial areas, affected by large-scale upwelling processes, present higher primary and export production rates compared to the subducting subtropical areas (Berger et al., 1987; Longhurst, 1995). Buesseler et al. (2007) obtained the same results when comparing the vertical fluxes of biogenic particles in the oligotropic subtropical and mesotrophic temperate North Pacific Ocean. Therefore, OUR values should be higher in the equatorial/subequatorial than in the subtropical South Atlantic. However, the residence time of the usually smaller organic particles of subduction areas (Clegg and Whitfield, 1990) is longer and, consequently, those particles have more time to be decomposed and consume oxygen within the water mass realms. Additionally, the vertical extension of Central Waters in the subtropical region of line A14 ( $\sim 400 \mathrm{dbar})$ was wider than in the equatorial-subequatorial region ( $\sim 200 \mathrm{dbar}$; see Fig. 1$)$. These facts would explain the non-significant difference between $\mathrm{OUR}_{\mathrm{T}}$ and $\mathrm{OUR}_{\Delta}$ for subequatorial SACW and the higher OUR $\mathrm{O}_{\Delta}$ for the subtropical variety. Concerning AAIW, high export production rates were reported in its formation area, east of the Drake Passage near the Subantartic Front (Usbeck et al., 2003). AAIW disperses in the SAO following the wind-driven circulation, being transported eastwards from its formation area by the South Atlantic Current.

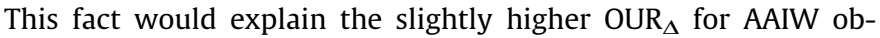
tained in line A14 (where small slow-sinking particles would be mineralized) compared with line A17 (where large fast-sinking particles would be mineralized).

The plots of the three OUR estimates $\left(\mathrm{OUR}_{\Delta}, \mathrm{OUR}_{\mathrm{T}}\right.$ and $\left.\mathrm{OUR}_{\mathrm{D}}\right)$ against the archetypal pressure of each water mass (Table 2) are shown in Fig. 5. The corresponding fitting equations with pressure $(p$, in dbar) are:

$$
\begin{array}{ll}
\text { OUR }_{\Delta}=11.5( \pm 1.2) \cdot \exp [0.8( \pm 0.3) \cdot p / 1000] & r^{2}=0.45 \\
n=9, \quad p<0.05 & \\
\text { OUR }_{\mathrm{T}}=10.4( \pm 1.1) \cdot \exp [1.3( \pm 0.2) \cdot p / 1000] & r^{2}=0.88, \\
n=9, \quad p<0.0002 & \\
\text { OUR }_{\mathrm{D}}=10.9( \pm 1.2) \cdot \exp [0.9( \pm 0.5) \cdot p / 1000] & r^{2}=0.38, \\
n=9, \quad p<0.08 &
\end{array}
$$

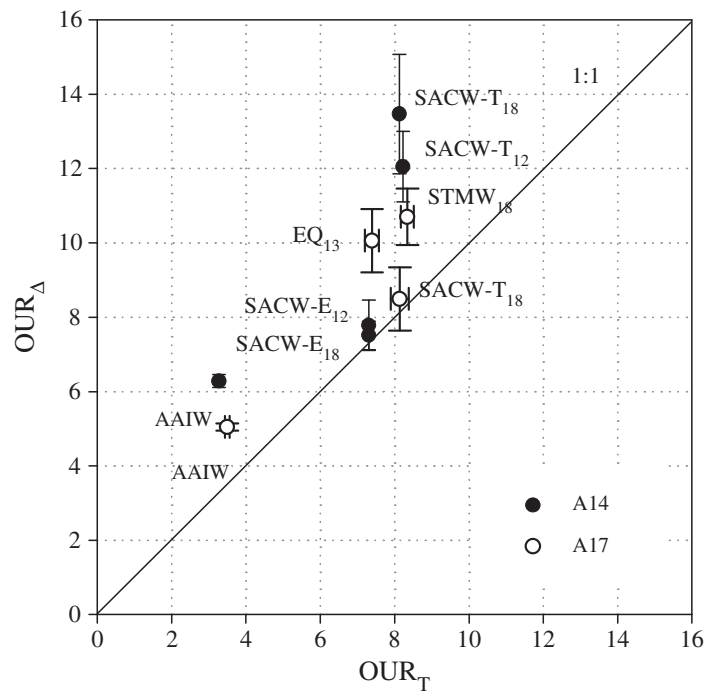

Fig. 4. Comparison of oxygen utilization rates calculated from OMP type $\left(\mathrm{OUR}_{\mathrm{T}}\right)$ and OMP residual $\left(\mathrm{OUR}_{\Delta}\right.$ ) values of $\mathrm{AOU}$ and $\mathrm{CFC11-derived} \mathrm{ages} \mathrm{in} \mathrm{the} \mathrm{realms} \mathrm{of}$ the central and intermediate water masses intercepted by WOCE lines A14 and A17. In $\mu \mathrm{mol} \mathrm{kg} \mathrm{kg}^{-1}$.
Although numerically higher OUR values were obtained with the OMP residuals (Eq. (12)), there were non-significant differences between Eqs. (12)-(14). Very few studies have reported respiration rates in the twilight zone, either using geochemical approaches based on AOU and age estimates, carbon budgets or box inversion models, or microbial approaches based on direct measurements of prokaryotic activity, and they differ considerably (Arístegui et al., 2003, 2005, 2009; Burd et al., 2010).

Arístegui et al. (2003) reviewed microbial respiration rates $(R)$ derived from ETS (Electron Transport System) measurements in the dark open ocean. Fitting their data for the 150-1000 dbar depth range to the same exponential equation than ours, we obtained a pre-exponential fitting parameter of $6.5 \pm 0.5 \mu \mathrm{mol} \mathrm{O}$ $\mathrm{kg}^{-1} \mathrm{yr}^{-1}$ and an exponential parameter of $0.9 \pm 0.1 \mathrm{dbar}^{-1}$ $\left(r^{2}=0.92, n=526, p<0.001\right)$. The pre-exponential parameter was about half the values obtained with Eqs. (12)-(14), but note that these authors applied the OUR:ETS ratio of 0.09 to convert ETS measurements to OURs assuming that only a fraction of the bacterial community was metabolically active. More recently, Baltar et al. (2009) recognised that this ratio might be somewhat higher at least in the mesopelagic zone, making the ETS and geochemically derived pre-exponential parameters more comparable. Regarding the exponential fitting parameter obtained with the ETS data, $0.9 \pm 0.1 \mathrm{dbar}^{-1}$, it was not significantly different from the fitting parameters obtained with Eqs. (12)-(14).

\section{Linking quality and lability of biogenic organic matter}

The quality of the mineralized materials (mean \pm STD of the range of $\mathrm{C} / \mathrm{N}_{\Delta}$ values reported in Table 7 ) was negatively correlated with the corresponding mineralization rate $\left(\mathrm{OUR}_{\Delta}\right)$ for each water mass (Fig. 6) with the following linear equation:

$(\mathrm{C} / \mathrm{N})_{\Delta}=7.9( \pm 0.5)-0.17( \pm 0.05) \cdot \mathrm{OUR}_{\Delta} \quad r^{2}=0.64$,

$n=8, \quad p<0.01$

According to this fitting equation, the more labile the material the faster it mineralizes. This result agrees with the conclusion about the existence of fractionation during the early decomposition of biogenic material reported in Section 5; nitrogen-rich compounds

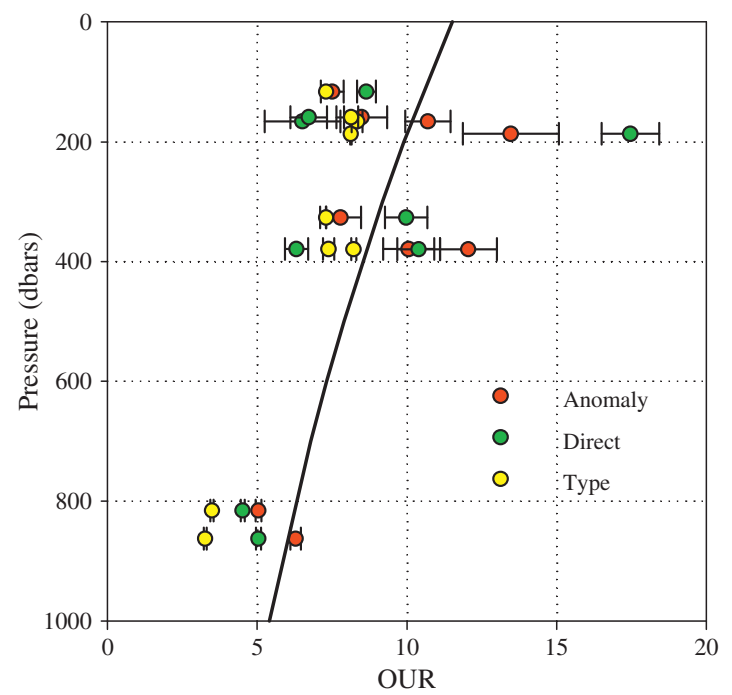

Fig. 5. Variation of oxygen utilization rates calculated from direct measurements (OUR $\left.R_{\mathrm{D}}\right)$, OMP type $\left(\mathrm{OUR}_{\mathrm{T}}\right)$ and OMP residuals $\left(\mathrm{OUR}_{\Delta}\right)$ values of AOU and CFC11derived ages (in $\mu \mathrm{mol} \mathrm{kg} \mathrm{kg}^{-1} \mathrm{y}^{-1}$ ) in the realms of the central and intermediate water masses intercepted by WOCE lines A14 and A17 with pressure (p, in dbar). Solid line, exponential decay regression equation of OUR $\mathrm{O}_{\Delta}$ versus $\mathrm{p}$ (see Eq. (12) in the text) 


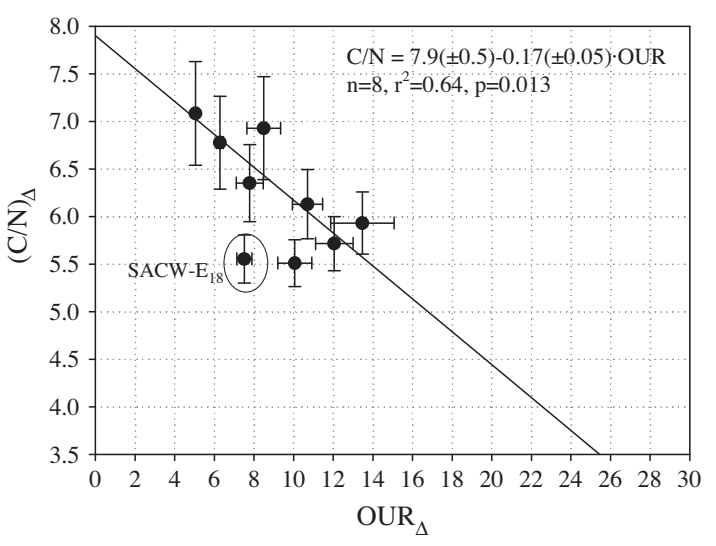

Fig. 6. Relationship between the $\mathrm{C} / \mathrm{N}$ molar ratio of mineralization $(\mathrm{C} / \mathrm{N})_{\Delta}$, (in mol $\mathrm{C}$ mol N${ }^{-1}$ ) and the oxygen utilization rate $\left(\mathrm{OUR}_{\Delta}\right)$ values of AOU and CFC11-derived ages (in $\mu \mathrm{mol} \mathrm{kg} \mathrm{g}^{-1}$ ) calculated from OMP residual values in the realms of the central and intermediate water masses intercepted by WOCE lines A14 and A17.

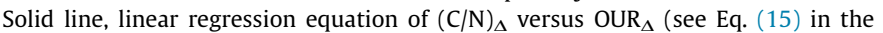
text).

(proteins and nucleic acids) are mineralized faster than carbon-rich compounds (carbohydrates and lipids). From Eq. (15) it can be estimated that a biogenic material with a $\mathrm{C} / \mathrm{N}$ molar ratio higher than $7.9 \pm 0.5$ will not be decomposed in the mesopelagic South Atlantic Ocean. According to Fraga et al. (1998) a biogenic material with this $\mathrm{C} / \mathrm{N}$ molar ratio would contain $36 \%$ of proteins $(\mathrm{w} / \mathrm{w}$ ). Therefore, no biogenic material will be decomposed in the mesopelagic South Atlantic Ocean with less than $36 \%$ of proteins. Eq. (15) could also tell us that: (i) pure proteins with a $\mathrm{C} / \mathrm{N}$ molar ratio of 3.7 (Table 3 ) would be mineralized at a rate of $25 \pm 12 \mu \mathrm{mol} \mathrm{kg}-1 \mathrm{yr}^{-1}$; and (ii) the mineralization rate for a material with a $\mathrm{C} / \mathrm{N}=4.5$, the characteristic cell $\mathrm{C} / \mathrm{N}$ quota of marine bacteria during active growth (Goldman and Dennett, 2000), will be $19 \pm 7 \mu \mathrm{mol} \mathrm{kg}^{-1} \mathrm{yr}^{-1}$ if Eq. (15) were still valid out of the 5.4-9.3 interval of $\mathrm{C} / \mathrm{N}$ molar ratios reported in Table 7.

Finally, combining Eq. (12) with Eq. (15), the following fitting equation was obtained to relate the oxygen utilization rate in the water masses occupying the mesopelagic South Atlantic with the quantity (modelled by a exponential decay with pressure) and quality (modelled by the $\mathrm{C} / \mathrm{N}$ ratio of the mineralized organic matter):

$$
\begin{gathered}
\operatorname{Ln}\left(\mathrm{OUR}_{\Delta}\right)=6.2( \pm 1.2)-2.0( \pm 0.7) \cdot \operatorname{Ln}\left((\mathrm{C} / \mathrm{N})_{\Delta}\right)-0.6( \pm 0.2) \cdot p / 1000 \\
r^{2}=0.87, \quad p<0.006, \quad n=9
\end{gathered}
$$

According to Eq. (16), the mineralization rates in the mesopelagic South Atlantic decreased quadratically with the $\mathrm{C} / \mathrm{N}$ molar ratio of the mineralised materials and exponentially with pressure. This equation should be introduced in biogeochemical models testing the potential of the ocean to sequester $\mathrm{CO}_{2}$ provided that faster mineralization of $\mathrm{N}$-rich compounds in shallow levels of the mesopelagic layer would undoubtedly reduce the residence time of $\mathrm{CO}_{2}$ in the oceans (Buesseler et al., 2007; Buesseler and Boyd, 2009; Kwon et al., 2009).

\section{Summary and conclusions}

After the first manuscript where an OMP analysis was presented and carefully assessed, we have used the OMP results to: (i) define the SWT realms as the group of samples with more than $50 \%$ contribution of the corresponding individual or combined SWT and, (ii) separate the effect of SWT mixing from mineralization processes in the inorganic nutrient and AOU variability. Most of the variability of these non-conservative properties was explained by mixing. Mineralization processes along the sections mostly altered the AOU, N, P and Si concentrations in the Central Waters realms of both basins. The main Intermediate water, AAIW, was largely affected by biogeochemical process as it occupied a large area of the South Atlantic with an archetypal depth (around 800900 dbar) where microbial activity was still high.

To study the ratios between inorganic nutrients and AOU, we have proposed a consensus least squares linear regression model which takes into account the relative error on both variables, $X^{\mathrm{var}}$ and $Y^{\mathrm{var}}$, to fulfil the discontinuity between the widely used models I and II. Ready-to-use functions to install in MATLAB and Excel are provided as Supplementary material.

If N/P ratios were only affected by mixing of OMP type nutrient concentrations, i.e. the $(\mathrm{N} / \mathrm{P})_{\mathrm{T}}$ ratios, they would vary between 16 and 18 in the Central Water realms, decrease to $15-16$ in the AAIW, further decrease to 14 in the UCDW and keep constant at deeper levels. This pattern was altered by local mineralization processes, accounted for by the $(\mathrm{N} / \mathrm{P})_{\Delta}$ ratios. Differences between $(\mathrm{N} / \mathrm{P})_{\mathrm{T}}$ and $(\mathrm{N} / \mathrm{P})_{\Delta}$ ratios were significantly higher within the western basin of the South Atlantic. OMP Nutrient type ratios were commonly higher than OMP nutrient residual ratios, indicating a preferential mineralization of $\mathrm{P}$ over $\mathrm{N}$, in agreement with the higher lability of phosphorous compounds compared with proteins. An exception to this rule occurred in the AAIW realm. This water extends all along the mesopelagic South Atlantic integrating the mineralization of both fresh and aged biogenic material. The nutrient residual ratios higher than the nutrient type ratios points to the prevalence of the mineralization of relatively aged biogenic matter.

Introducing the calculated $R_{\mathrm{N}}$ and $R_{\mathrm{P}}$ ratios in the stoichiometric model of Fraga et al. (1998), we estimated the average biochemical composition of the mineralized biogenic material. This work evidences a significant fractionation of the organic matter mineralized in the South Atlantic Ocean, with nitrogenrich compounds being mineralised faster than carbon-rich compounds. The $\mathrm{C} / \mathrm{N}$ mineralization ratio was $6.1 \pm 0.2 \mathrm{~mol} \mathrm{C} \mathrm{mol} \mathrm{N}{ }^{-1}$ in the Central Waters realm and increased with pressure at a rate of $0.5 \pm 0.2 \mathrm{~mol} \mathrm{C} \mathrm{mol} \mathrm{N}^{-1}$ every $1000 \mathrm{dbar}$ (depth range between 126 and 3300 dbar).

Finally, oxygen utilization rates were calculated for the SAO Central and Intermediate water masses combining AOU and CFC11 derived ages. OUR values ranged from 3 to $18 \mu \mathrm{mol} \mathrm{O} \mathrm{kg}^{-}$ ${ }^{1} \mathrm{yr}^{-1}$, decreasing quadratically with the $\mathrm{C} / \mathrm{N}$ molar ratio of the mineralized material and exponentially with pressure. The differential depth dependence of the $\mathrm{C} / \mathrm{N}$ and $\mathrm{N} / \mathrm{P}$ mineralization ratios and OURs have important implications for modelling the nutrient and carbon cycling accounted for by the biological pump and also to predict its feedback mechanisms due to global change (Omta et al., 2006; Schneider et al., 2004; Buesseler et al., 2007; Buesseler and Boyd, 2009; Kwon et al., 2009).

\section{Acknowledgements}

The authors wish to thank the captain and the crew of R/V Maurice Ewing and R/V L'Atalante for their help during the cruises. We are very grateful to C.G. Castro and M.J. Pazó for their participation in nutrient measurements. Financial support from this work came from the Spanish CICYT Contracts ANT93-1156-E and ANT941168-E and, and from the IFREMER Contract No. 941430087. X.A.A.S. and M.A. were supported by the Spanish Ministry of Science and Innovation (MALASPINA expedition, Grant No. CSD2008-00077). M.A. was funded by the grant ORCASEX (RYC2006-001836), program Ramón y Cajal from the Spanish Ministry of Science and Technology. 


\section{Appendix A. Supplementary material}

Supplementary data associated with this article can be found, in the online version, at http://dx.doi.org/10.1016/j.pocean.2013.12. 009.

\section{References}

Álvarez, M., Brea, S., Arhan, M., Mercier, H., Álvarez-Salgado, X.A., 2013. Mineralization of biogenic materials in the water masses of the South Atlantic Ocean. I: assessment and results of an optimum multiparameter analysis (this issue).

Álvarez-Salgado, X.A., Nieto-Cid, M., Gago, J., Brea, S., Castro, C.G., Doval, M.D., Pérez, F.F., 2006. Stoichiometry of the mineralization of dissolved and particulate biogenic organic matter in the NW Iberian upwelling. Journal of Geophysical Research 111, C07017. http://dx.doi.org/10.1029/2004JC002473.

Álvarez-Salgado, X.A., Nieto-Cid, M., Álvarez, M., Pérez, F.F., Morin, P., Mercier, H., 2013. New insights on the mineralization of dissolved organic matter in central, intermediate, and deep-water masses of the northeast North Atlantic. Limnology and Oceanography 58, 681-696. http://dx.doi.org/10.4319/ lo.2013.58.2.0681.

Anderson, L.A., 1995. On the hydrogen and oxygen content of marine phytoplankton. Deep Sea Res. I 42, 1675-1680.

Anderson, L.A., Sarmiento, J.L., 1994. Redfield ratios of remineralization determined by nutrient data analysis. Global Biogeochemical Cycles 8, 65-80.

Arístegui, J.S., Agustí, S., Duarte, C.M., 2003. Respiration in the dark ocean. Geophysical Research Letters 30 (1041), 2003. http://dx.doi.org/10.1029/ 2002 GL016227.

Arístegui, J.S., Agustí, S., Middelburg, J.J., Duarte, C.M., 2005. Respiration in the Mesopelagic and Bathypelagic Zones of the Ocean. Oxford University Press.

Arístegui, J., Gasol, J.M., Duarte, C.M., Herndl, G.J., 2009. Microbial oceanography of the dark ocean's pelagic realm. Limnology and Oceanography 54, 1501-1529.

Asper, V.L., 1987. Measuring the flux and sinking speed of marine snow aggregates. Deep-Sea Research 34, 1-17

Baltar, F., Arístegui, J., Gasol, J.M., Sintes, E., Herndl, G.J., 2009. Evidence of prokaryotic metabolism on suspended particulate organic matter in the dark waters of the subtropical North Atlantic. Limnology and Oceanography 54, 182193.

Berger, W.H., Wefer, G., 2002. On the reconstruction of upwelling history: Namibia upwelling in context. Marine Geology 180, 3-28.

Berger, W.H., Fischer, K., Lai, C., Wu, G., 1987. Ocean Productivity and Organic Carbon Flux. Part 1. Overview and Maps of Primary Production and Export Production. Univ. Calif., San Diego, SIO Ref. 87-30, 67 p.

Boulahdid, M., Minster, J.F., 1989. Oxygen consumption and nutrient regeneration ratios along isopycnal horizons in the Pacific Ocean. Marine Chemistry 26, $133-$ 153.

Boyd, P.W., Trull, T.W., 2007. Understanding the export of biogenic particles in oceanic waters: is there consensus? Progress in Oceanography 72, 276-312.

Brea, S., Álvarez-Salgado, X.A., Álvarez, M., Pérez, F.F., Mémery, L., Mercier, H., Messias, M.J., 2004. Nutrient mineralization rates and ratios in the eastern South Atlantic. Journal of Geophysical Research 109, C05030. http://dx.doi.org/ 10.1029/2003JC002051.

Broecker, W.S., Peng, T.H., 1982. Tracers in the Sea. Lamont-Doherty Earth Observatory, Palisades, N.Y.

Broecker, W.S., Takahashi, T., Takahashi, T., 1985. Sources and flow patterns of deepocean waters as deduced from potential temperature, salinity and initial phosphate concentration. Journal of Geophysical Research 90, 6925-6939.

Buesseler, K.O., Boyd, P.W., 2009. Shedding light on processes that control particle export and flux attenuation in the twilight zone of the open ocean. Limnology and Oceanography 54, 1210-1232.

Buesseler, K.O., Lamborg, C.H., Boyd, P.W., et al., 2007. Revisiting carbon flux through the ocean's twilight zone. Science 316, 567-570.

Bullister, J.L., Weiss, R.F., 1988. Determination of $\mathrm{CC}_{3}{ }_{3} \mathrm{~F}$ and $\mathrm{CC}_{2} \mathrm{~F}_{2}$ in seawater and air. Deep Sea Research 35, 839-853.

Burd, A.B., Hansell, D.A., Steinberg, D.K., Anderson, T.R., Arístegui, J., Baltar, F., Beaupre, S.R., Beusseler, K.O., De Hairs, F., Jackson, G.A., Kadko, D., Koppelmann, R., Lampitt, R.S., Nagata, T., Reinthaler, T., Robinson, C., Robison, B.H., Tamburini, C., Tanaka, T., 2010. Assessing the apparent imbalance between geochemical and biochemical indicators of meso-and bathypelagic biological activity: what the @\$\#! Is wrong with present calculations of carbon budgets? Deep-Sea Research II 57, 1557-1571.

Calbet, A., Prairie, Y.T., 2003. Mesozooplankton grazing and primary production: reply to the comment by Laws. Limnology and Oceanography 48, 1359-1362.

Carlson, C.A., Hansell, D.A., Nelson, N.B., Siegel, D.A., Smethie, W.M.J., Khatiwala, S., Meyers, M.M., Halewood, E., 2010. Dissolved organic carbon export and subsequent remineralization in the mesopelagic and bathypelagic realms of the North Atlantic basin. Deep-Sea Research II 57, 1433-1445.

Carrol, R., Ruppert, D., 1996. The use and misuse of orthogonal regression in measurement error models. American Statistician 50, 1-6.

Castro, C.G., Pérez, F.F., Holley, S.E., Rios, A.F., 1998. Chemical characterization and modelling of water masses in the Northeast Atlantic. Progress in Oceanography 41, 249-279.
Chester, R., 2000. Marine Geochemistry, second ed. Blackwell, Malden, Mass,

Clegg, S.L., Whitfield, M., 1990. A generalized model for the scavenging of trace metals in the open ocean I: Particle cycling. Deep-Sea Research 37, 809-832.

Del Giorgio, P., Duarte, C.M., 2002. Respiration in the open ocean. Science 420, 379 384.

Doney, S., Bullister, J.L., 1992. A chlorofluorocarbon section in the eastern North Atlantic. Deep-Sea Research 39, 1857-1883.

Doney, S., Bullister, J., 1997. A comparison of ocean tracer dating techniques on a meridional section in the eastern North Atlantic. Deep-Sea Research 44, 603-626.

Fraga, F., Ríos, A.F., Pérez, F.F., Figueiras, F.G., 1998. Theoretical limits of oxygen:carbon and oxygen:nitrogen ratios during photosynthesis and mineralization of organic matter in the sea. Scientia Marina 62, 161-168.

Fuller, W.A., 1987. Measurement Error Models. Wiley.

Goldman, J.C., Dennett, M.R., 2000. Growth of marine bacteria in batch and continuous culture under carbon and nitrogen limitation. Limnology and Oceanography 45, 789-800.

Gouretski, V.V., Jancke, K., 2001. Systematic errors as the cause for an apparent deep water property variability global analysis of the WOCE and historica hydrographic data. Progress in Oceanography 48, 337-402.

Groupe CITHER-2, 1996. Recueil de données, Campagne CITHER 2, N/O Maurice Ewing (4 janvier-21 mars 1994), vol. 3, Traceurs géochimiques, Rapport Interne LPO 96-02, Laboratoire de Physique des Océans/IFREMER, Centre de Brest, Plouzané, France, 560 pp.

Groupe CITHER-3, 1998. Recueil de données, Campagne CITHER 3, N/O L'Atalante (11 janvier-2 avril 1995), vol. 3, Traceurs Géochimiques, Rapport Interne LPO 98-03, Laboratoire de Physique des Océans/IFREMER, Centre de Brest, Plouzané, France, 586 pp.

Gruber, N., Sarmiento, J.L., Stocker, T.F., 1996. An improved method for detecting anthropogenic $\mathrm{CO}_{2}$ in the oceans. Global Biogeochemical Cycles 10, 809-837.

Gruber, N., Keller, K., Key, R.M., 2000. What story is told by oceanic tracer concentrations? Science 290, 455-456.

Guerrero-Feijóo, E., Nieto-Cid, M., Álvarez, M., Álvarez-Salgado, X.A., 2014. Dissolved organic matter cycling in the confluence of the Atlantic and Indian oceans south of Africa. Deep Sea Research I 83, 12-23. http://dx.doi.org/ 10.1016/j.dsr.2013.08.008.

Hopkinson Jr., C.S., Vallino, J.J., 2005. Efficient export of carbon to the deep ocean through dissolved organic matter. Nature 433, 142-145.

Hopkinson Jr., C.S., Vallino, J.J., Nolin, A., 2002. Decomposition of dissolved organic matter from the continental margin. Deep Sea Res. II 49, 4461-4478.

Hupe, A., Karstensen, J., 2000. Redfield stoichiometry in Arabian Sea subsurface waters. Global Biogeochemical Cycles 14, 357-372.

Jenkins, W.J., 1998. Studying subtropical thermocline ventilation and circulation using tritium and ${ }^{3} \mathrm{He}$. Journal of Geophysical Research 103, 15817-15831.

Karstensen, Tomczak, M., 1998. Age determination of mixed water masses using CFC and oxygen data. Journal of Geophysical Research 103, 18599-18609.

Kwon, E.W., Primeau, F., Sarmiento, J.L., 2009. The impact of remineralization depth on the air-sea carbon balance. Nature Geosciences 2, 630-635.

Laws, E.A., 2003. Mesozooplankton grazing and primary production: an alternate assessment. Limnology and Oceanography 48, 1357-1359.

Laws, E.A., Archie, J.M., 1981. Appropriate use of regression analysis in marine biology. Marine Biology 65, 13-16.

Li, Y.H., Peng, T.H., 2002. Latitudinal change of remineralization ratios in the oceans and its implication for nutrient cycles. Global Biogeochemical Cycles 16, 1130 http://dx.doi.org/10.1029/2001GB001828.

Li, Y.H., Karl, D.M., Winn, C.D., Mackenzie, F.T., Gans, K., 2000. Remineralization ratios in the subtropical North Pacific Gyre. Aquatic Geochemistry 6, 65-86.

Lønborg, C., Álvarez-Salgado, X.A., 2012. Recycling versus export of bioavailable dissolved organic matter in the coastal ocean and efficiency of the continental shelf pump. Global Biogeochemical Cycles 26, GB3018. http://dx.doi.org/ 10.1029/2012GB004353.

Lønborg, C., Davidson, K., Álvarez-Salgado, X.A., Miller, A.E.J., 2009. Bioavailability and bacterial degradation rates of dissolved organic matter in a temperate coastal area during an annual cycle. Marine Chemistry 113, 219-226.

Longhurst, A., 1995. Seasonal cycles of pelagic production and consumption. Progress in Oceanography 36, 77-167.

McArdle, B.H., 2003. Lines, models, and errors: regression in the field. Limnology and Oceanography 48, 1363-1366.

Mecking, S., Warner, M., Greene, C., Hautala, S., Sonnerup, R., 2004. Influence of mixing on CFC uptake and CFC ages in the North Pacific thermocline. Journal of Geophysical Research 109. http://dx.doi.org/10.1029/2003JC001988.

Middelburg, J.J., Vlug, T., van der Nat, F.J.W.A., 1993. Organic matter mineralization in marine systems. Global Planetary Change 8, 47-58.

Minster, J.F., Boulahdid, M., 1987. Redfield ratios along isopycnal surfaces: a complementary study. Deep-Sea Research Part A 34, 1981-2003.

Omta, A.W., Bruggeman, J., Kooijman, S.A.L.M., Dijkstra, H.A., 2006. Biological carbon pump revisited: feedback mechanisms between climate and the Redfield ratio. Geophysical Research Letters 33, L14613. http://dx.doi.org/10.1029/ 2006GL026213.

Pahlow, M., Riebesell, U., 2000. Temporal trends in deep ocean Redfield ratios. Science $287,831-833$.

Peng, T.H., Broecker, W.S., 1987. C/P ratios in marine detritus. Global Biogeochemical Cycles 1, 155-161.

Pérez, F.F., Mouriño, C., Fraga, F., Ríos, A.F., 1993. Displacement of water masses and remineralization rates off the Iberian Peninsula by nutrient anomalies. Journal of Marine Research 51, 869-892. 
Prairie, Y.T., Peters, R.H., Bird, D.F., 1995. Natural variability and the estimation of empirical relationships: a reassessment of the regression methods. Canadian Journal of Fisheries and Aquatic Sciences 52, 788-798.

Ricker, W.E., 1973. Linear regression in fishery research. Journal of the Fisheries Research Board of Canada 30, 409-434.

Ríos, A.F., Alvarez-Salgado, X.A., Pérez, F.F., Bingler, L.S., Arístegui, J., Mémery, L., 2003. Carbon dioxide along WOCE line A14: water masses characterization and anthropogenic entry. Journal of Geophysical Research 108. http://dx.doi.org/ 10.1029/2000JC000366.

Ríos, A.F., Vázquez-Rodríguez, M., Padín, X.A., Pérez, F.F., 2010. Anthropogenic carbon dioxide in the South Atlantic western basin. Journal of Marine Systems 83, 38-44.

Sabine, C.L., Feely, R.A., Gruber, N., et al., 2004. The oceanic sink for anthropogenic $\mathrm{CO}_{2}$. Science $305,367-371$

Sarmiento, J.L., Gruber, N., 2006. Ocean Biogeochemical Dynamics. Princeton University Press, Princeton.

Sarmiento, J., Thiele, G., Key, R., Moore, W., 1990. Oxygen and nitrate new production and remineralization in the North Atlantic subtropical gyre. Journal of Geophysical Research 95. http://dx.doi.org/10.1029/90JC01049.

Schneider, B., Schlitzer, R., Fischer, G., Noethig, E.-M., 2003. Depth-dependent elemental compositions of particulate organic matter (POM) in the ocean Global Biogeochemical Cycles 17, 1032, 10.029/2002GB001871.

Schneider, B., Engel, A., Schlitzer, R., 2004. Effects of depth- and $\mathrm{CO}_{2}$-dependent C: N ratios of particulate organic matter (POM) on the marine carbon cycle. Global Biogeochemical Cycles 18, GB2015. http://dx.doi.org/10.1029/2003GB002184.

Shaffer, G., Bendtsen, J., Ulloa, O., 1999. Fractionating during remineralization of organic matter in the ocean. Deep-Sea Research I 46, 185-204.

Sokal, R.R., Rohlf, F.J., 1995. Biometry: the principles and practice of statistics in biological research, 3rd edition. W. H. Freeman and Co., New York, 887 pp. ISBN: 0-7167-2411-1.

Sonnerup, R.E., 2001. On the relations among CFC derived water mass ages. Geophysical Research Letters 28, 1739-1742.

Suess, E., Müller, P.J., 1980. Productivity, sedimentation rate and sedimentary organic matter in the oceans. II. Elemental fractionation. In: Proceedings of the C.N.R.S. Symposium on the Benthic Boundary Layer, Marseille, France, pp. 1726.

Takahashi, T., Broecker, W.S., Langer, S., 1985. Redfield ratio based on chemical data from isopycnal surfaces. Journal of Geophysical Research 90, 6907-6924.

Tanhua, T., van Heuven, S., Key, R.M., Velo, A., Olsen, A., Schirnick, C., 2010. Quality control procedures and methods of the CARINA database. Earth System Science Data 2, 35-49.
Tegelaar, E.W., De Leeuw, J.W., Derenne, S., Largeau, C., 1989. A reappraisal of kerogen formation. Geochimica Cosmochima Acta 53, 3103-3106.

Thiele, G., Sarmiento, J.L., 1990. Tracer dating and ocean ventilation. Journal of Geophysical Research 95, 9377-9391.

Thomas, H., 2002. Remineralisation ratios of carbon, nutrients and oxygen in the North Atlantic Ocean: a field data based assessment. Global Biogeochemical Cycles 16, 1051. http://dx.doi.org/10.1029/2001GB001452.

Tomczak, M., 1999. Some historical, theoretical and applied aspects of quantitative water mass analysis. Journal of Marine Research 57, 275-303.

Touratier, F., Goyet, C., 2004a. Definition, properties, and Atlantic distribution of the new tracer TrOCA. Journal of Marine Systems 46, 169-179.

Touratier, F., Goyet, C., 2004b. Applying the new TrOCA approach to assess the distribution of anthropogenic $\mathrm{CO}_{2}$ in the Atlantic Ocean. Journal of Marine Systems 46, 181-197.

Touratier, F., Azouzi, L., Goyet, C., 2007. CFC-11, $\Delta{ }^{14} \mathrm{C}$ and ${ }^{3} \mathrm{H}$ tracers as a means to assess anthropogenic $\mathrm{CO}_{2}$ concentrations in the ocean. Tellus 59B, 318-325.

Usbeck, R., Schlitzer, R., Fischer, G., Wefer, G., 2003. Particle fluxes in the ocean: comparison of sediment trap data with results from inverse modelling. Journal of Marine Systems 39, 167-183.

Walker, S.J., Weiss, R.F., Salameh, P.K., 2000. Reconstructed histories of the annual mean atmospheric mole fractions for the halocarbons CFC-11, CFC-12, CFC-113 and carbon tetrachloride. Journal of Geophysical Research 105, 14285-14296.

Wallace, D.W.R. Lazier, J.R.N., 1988. Anthropogenic chlorofluoromethanes in newly formed Labrador Seawater. Nature 332, 61-63.

Wallace, D.W., Beininga, P., Putzka, A., 1994. Carbon tetrachloride and chlorofluorocarbons in the South Atlantic Ocean. Journal of Geophysical Research 99, 7803-7819.

Warner, M.J., Weiss, R.F., 1985. Solubilities of chlorofluorocarbons 11 and 12 in water and seawater. Deep-Sea Research 32, 1485-1497.

Warner, M.J., Weiss, R.F., 1992. Chlorofluoromethanes in the South Atlantic intermediate water. Deep Sea Research 39, 2053-2075.

Warton, D.I., Wright, I.J., Falster, D.S., Westoby, M., 2006. Bivariate line-fitting methods for allometry. Biological Reviews 81, 259-291.

Weber, T.S., Deutsch, C., 2010. Ocean nutrient ratios governed by plankton biogeography. Nature 467, 550-554.

Wong, C.S., Waser, N.A.D., Whitney, F.A., Johnson, W.K., Page, J.S., 2002. Time series study of the biogeochemistry of the North East subarctic Pacific: reconciliation of the Corg/N remineralization and uptake ratios with the Redfield ratios. DeepSea Research II 49, 5717-5738.

Zhang, J.Z., Mordy, C.W., Gordon, L.I., Ross, A., Garcia, H.E., 2000. Temporal trends in deep ocean Redfield ratios. Science 289, 1839a. 